\title{
ALUR TRANSMISI DAN EFEKTIFITAS KEBIJAKAN MONETER GANDA DI INDONESIA
}

\author{
Ascarya $^{1}$
}

\begin{abstract}
This study aims to investigate transmission mechanism of dual monetary system from conventional and Islamic policy rates to inflation and output using Granger and VAR methods on monthly Indonesian banking data form January 2003 to December 2009. The result shows that conventional transmission mechanismsfrom conventional policy rate are all linked tooutput and inflation, while Islamic policy rate are not linked to output and inflation. In addition, the interest rate, credit and conventional interbank rate shocks give negative and permanent impacts to inflation and output, while PLS, financing and Islamic interbank PLS, as well as SBIS(Central Bank Shariah Certificate) as Islamic policy rate shocks give positive and permanent impacts to inflation and output. SBI (Central Bank Certificate) as conventional policy givespositive impact to inflation and negative impact to output.
\end{abstract}

Keywords: Monetary transmission mechanism, Interest rate pass through, Conventional Banking, Islamic Banking JEL Classification: E43, E52, G21, G28

1 Peneliti pada Pusat Penelitian dan Studi Kebanksentralan, Bank Indonesia; ascarya@bi.go.id 


\section{PENDAHULUAN}

\subsection{Latar Belakang}

Kebijakan moneter suatu bank sentral atau otoritas moneter dimaksudkan untuk mempengaruhi kegiatan ekonomi riil dan harga melalui mekanisme transmisi yang terjadi. Untuk itu, otoritas moneter harus memiliki pemahaman yang jelas tentang mekanisme transmisi di negaranya. Mekanisme transmisi kebijakan moneter dapat bekerja melalui berbagai saluran, seperti suku bunga, agregat moneter, kredit, nilai tukar, harga aset, dan ekspektasi (Warjiyo dan Agung, 2002). Sehingga, pemahaman tentang transmisi kebijakan moneter menjadi kunci agar dapat mengarahkan kebijakan moneter untuk mempengaruhi arah perkembangan ekonomi riil dan harga di masa yang akan datang.

Sementara itu, sejak dikeluarkannya UU Perbankan yang baru tahun 1998, Indonesia secara de jure telah menerapkan sistem perbankan ganda, ketika bank konvensional dan bank syariah dapat beroperasi berdampingan di seluruh wilayah Indonesia. Sedangkan, sejak dikeluarkannya UU Bank Indonesia yang baru tahun 1999, Bank Indonesia telah diberi amanah sebagai otoritas moneter ganda yang dapat menjalankan kebijakan moneter konvensional maupun syariah. Sejak saat itu perbankan dan keuangan syariah berkembang pesat.

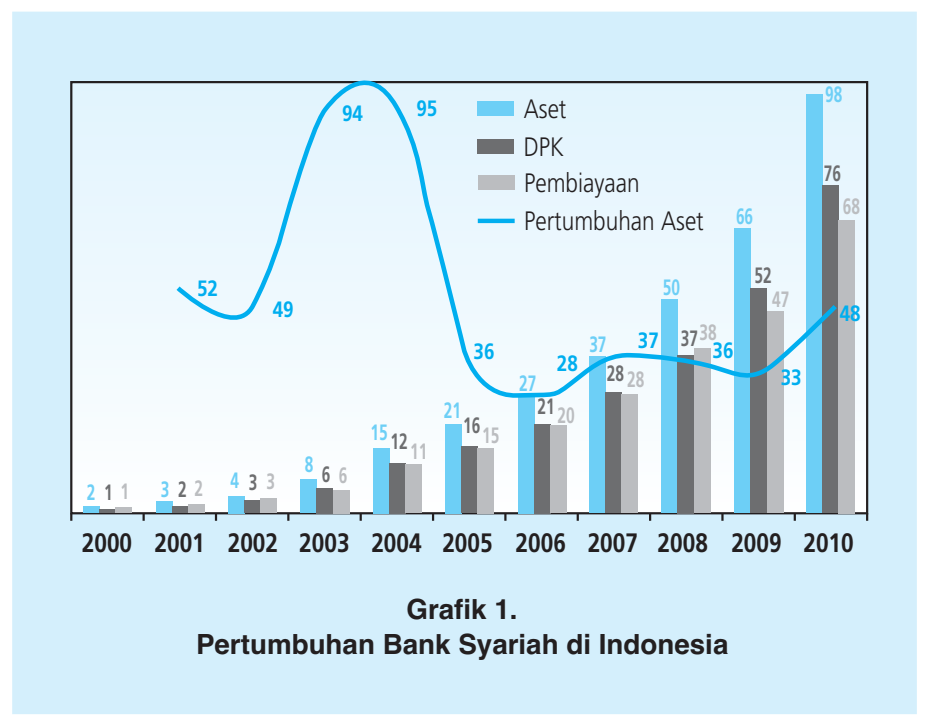

Pada tahun 2000, ada dua bank syariah dan tiga unit usaha syariah (UUS) dengan 65 kantor dan hanya menguasai 0,17\% dari total asset. Sementara pada akhir 2010, sudah berdiri1 1 bank syariah dan 23 UUSdengan total 1477 kantor dan 1277 loket office channeling di bank konvensional. Pangsa pasar bank syariah telah mencapai 3,24\% dari total aset atau 97,52 triliun rupiah dengan $48 \%$ pertumbuhan per tahun. 
Pertumbuhan bank syariah di Indonesia dapat dilihat dari jumlah simpanan dan perluasan pembiayaan. Pada tahun 2000, jumlah simpanan mencapai 1,03 triliun rupiah dan pembiayaan mencapai 1,27 triliun rupiah, dengan FDR (financing to deposit ratio) 123\%. Pada akhir tahun 2010, jumlah simpanan tumbuh 45,47\% per tahun dan mencapai 76,04 triliun rupiah, sedangkan pembiayaan tumbuh 45,42\% per tahun dan mencapai 68,18 triliun rupiah, dengan FDR $89,67 \%$. Tingkat FDR ini merupakan pencapaian yang tinggi, jika dibandingkan dengan bank syariah di negara-negara lain, dan juga jauh melampaui LDR (loan to deposit ratio) bank konvensional di Indonesia, yang hanya mencapai 75,21\%.

Dari sisi moneter, Bank Indonesia memperkenalkan instrumen moneter syariah pertama pada tahun 2000, yaitu Sertifikat Wadi'ah Bank Indonesia (SWBI), yang masih bersifat pasif. Dengan semakin tumbuh pesatnya perbankan syariah, pada tahun 2008 Bank Indonesia mengganti SWBI dengan instrumen moneter syariah yang lebih baik, yaitu Sertifikat Bank Indonesia Syariah (SBIS) yang berdasarkan pada akad Ju'alah.
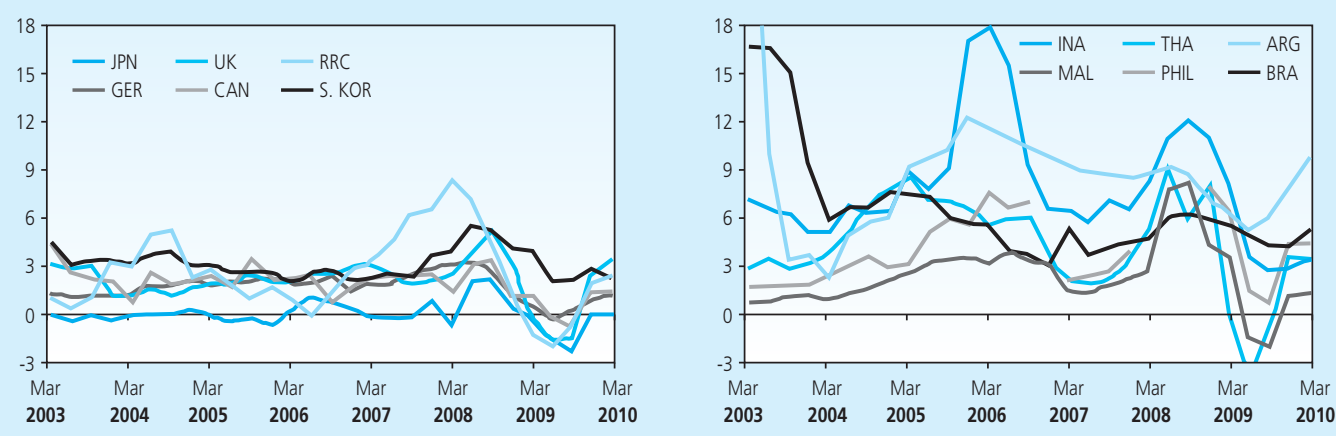

Grafik 2.

Inflasi di Beberapa Negara Penganut Inflation Targeting

Sementara itu, sejak Juli 2005 Bank Indonesia sebagai otoritas moneter di Indonesia telah menerapkan full-fledged inflation targeting, yaitu framework kebijakan moneter yang dicirikan dengan pengumuman resmi target inflasi untuk rentang waktu tertentu dan kebijakan moneter dilaksanakan oleh bank sentral yang independen untuk mencapai target dengan tingkat transparansi dan kredibilitas yang tinggi. Inflation targeting framework telah diterapkan oleh sebagian besar bank sentral, khususnya di negara maju, dalam tujuh belas tahun terakhir, sehingga transmisi suku bunga (interest rate pass-through) telah lebih banyak menarik perhatian dari sebelumnya. Penerapan inflation targeting framework secara empiris terbukti di beberapa negara maju maupun negara berkembang dapat mengontrol inflasi pada tingkat yang relatif rendah (baca Grafik 2), kecuali Argentina dan Indonesia. 

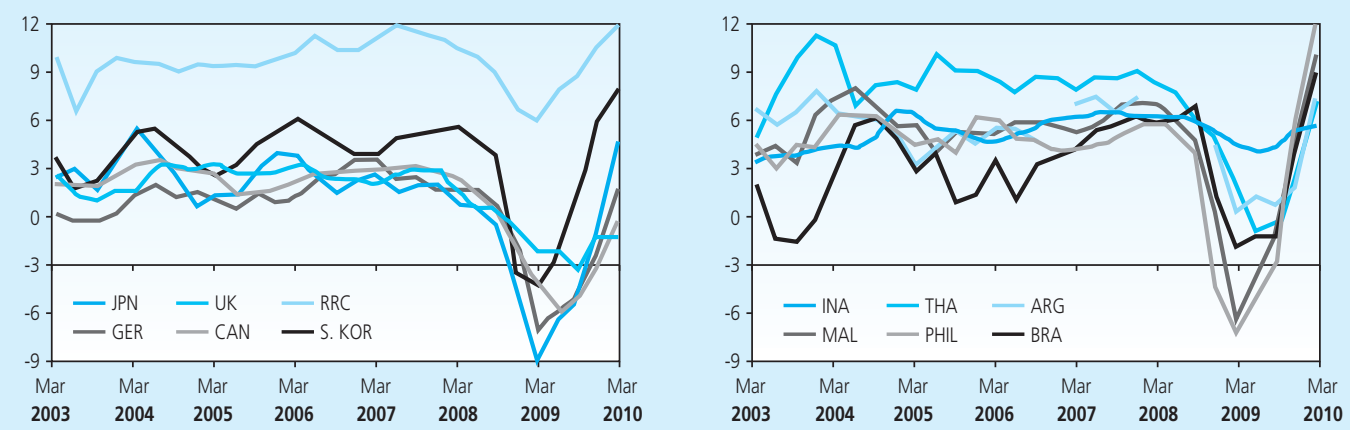

Grafik 3.

Pertumbuhan Ekonomi di Beberapa Negara Penganut Inflation Targeting

Namun demikian, negara-negara maju hanya membukukan pertumbuhan ekonomi yang juga rendah sekitar 2 - 3 persen. Sedangkan, Negara-negara Asean dan Amerika Latin dapat mencapai pertumbuhan ekonomi lebih tinggi sekitar $4-6$ persen. Negara yang paling menonjol pertumbuhan ekonominya adalah Cina, disusul oleh Argentina. Sementara itu, pertumbuhan ekonomi Indonesia cukup stabil di kisaran 4 - 6 persen, termasuk pada masa krisis finansial global (lihat Grafik 3).

Interest rate pass-through menggambarkan derajat dan kecepatan penyesuaian market rate terhadap perubahan suku bunga kebijakan yang ditetapkan oleh bank sentral. Interest rate pass-through merupakan salah satu prasyarat berjalannya transmisi kebijakan moneter melalui jalur suku bunga. Jalur transmisi melalui saluran suku bunga menekankan pentingnya aspek harga di pasar keuangan terhadap berbagai aktivitas ekonomi di sektor riil.

Dengan semakin berkembangnya perbankan syariah, transmisi kebijakan moneter tidak hanya mempengaruhi perbankan konvensional saja, namun juga mempengaruhi perbankan syariah, karena mekanisme transmisi dapat juga melewati jalur syariah. Instrumen kebijakan moneter ganda juga tidak terbatas hanya menggunakan suku bunga saja, tetapi dapat pula menggunakan bagi hasil atau margin atau fee. Dengan demikian, dalam sistem moneter ganda, interest rate pass-through lebih tepat disebut policy rate pass-through, dimana policy rate untuk konvensional menggunakan suku bunga, sedangkan policy rate untuk syariah dapat menggunakan bagi hasil, margin, atau fee.

Oleh karena itu perlu dilakukan penelitian tentang mekanisme transmisi kebijakan moneter konvensional dan syariah dalam sistem perbankan ganda Indonesia, untuk mengetahui alur transmisi dan efektifitas kebijakan moneter ganda dalam sistem perbankan ganda. 
Tujuan dari paper ini pertama adalah mengidentifikasi alur transmisi kebijakan moneter ganda di Indonesia melalui jalur konvensional suku bunga dan melalui jalur syariah bagi hasil/ margin/fee dan keterkaitan keduanya dan melihat dampaknya terhadap sasaran akhir pengendalian inflasi. Kedua, melihat sejauh mana suku bunga bank konvensional bergerak mengikuti suku bunga kebijakan dan bagi hasil/margin/fee bank syariah bergerak mengikuti bagi hasil/margin/fee kebijakan dalam jangka pendek maupun jangka panjang, serta melihat perbandingan kecepatan transmisi kebijakan moneter konvensional dan syariah. Ketiga, memformulasikan kebijakan moneter ganda yang efektif dari hasil 1) dan 2) untuk mencapai kesejahteraan masyarakat yang merata dan adil.

Bagian kedua dari paper ini mengulas teori dan studi literatur, bagian ketiga membahas metodologi dan data yang digunakan, sementara bagian keempat mengulas hasil dan analisis. Kesimpulan akan diberikan pada bagian kelima dan menjadi bagian penutup.

\section{TEORI}

Dalam dunia yang didominasi oleh ekonomi dan keuangan kapitalis (konvensional), kebijakan moneter yang dikenal luas adalah kebijakan moneter dalam perspektif konvensional. Sejak 30 tahun terakhir, ekonomi dan keuangan Islam telah secara bertahap diterapkan di berbagai negara, secara tunggal maupun berdampingan dengan yang konvensional. Dengan semakin besar dan signifikannya ekonomi dan keuangan Islam, kebijakan moneter dalam perspektif Islamjuga ikut berkembang.

Di negara-negara yang menerapkansistem keuangan ganda, seperti Pakistan, Malaysia dan Indonesia, bank sentralnya harus melakukan kebijakan moneter konvensional maupun kebijakan moneter Islam untuk dapat secara efektif mempengaruhi situasi makroekonomi secara menyeluruh.

Dalam literatur ekonomi konvensional, menurut Djohanputro (2006), Kebijakan moneter merupakan tindakan pemerintah dalam rangka mencapai tujuan pengelolaan ekonomi makro (output, harga dan pengangguran) dengan cara mempengaruhi situasi makro melalui pasar uang atau dengan kata lain melalui proses penciptaan uang atau jumlah uang beredar. Demikian halnya yang dikemukakan oleh Bofinger (2001) yang menyatakan bahwa "monetary policy is manipulating of monetary instruments in order to achieve price stability, low unemployment and sustainable economic growth". Institusi yang diberikan otoritas untuk melaksanakan kebijakan moneter ini biasanya berbentuk bank sentral atau monetary authority suatu negara sebagai wakil dari pemerintah.

Hal ini berlandaskan pada pemikiran aliran monetarist yang mengemukakan bahwa pertumbuhan uang beredar merupakan unsur yang dapat diandalkan dalam perkembangan moneter. Pendiri mazhab monetarist, Milton Friedman, mengatakan bahwa perubahan dalam jumlah uang beredar sangat berpengaruh pada tingkat inflasi pada jangka panjang dan juga 
perilaku Gross National Product (GNP) riil. Selain itu aliran monetarist mengemukakan adanya kekuatan pasar dan pengaruh sumberdaya yang menyatakan turunnya suku bunga akan mendorong investasi dan turunnya tingkat harga akan mendorong konsumsi (pigou effect). Hal lainnya adalah pendapat kaum monetaris mengenai fluktuasi ekonomi yang terjadi karena terjadinya lonjakan dalam jumlah uang beredar yang disebabkan karena kebijakan yang ekspansif yang diambil oleh pemerintah. Aliran monetarist lebih menggerakkan ekonomi dari sisi moneter, yang sangat berlawanan dengan aliran Keynesian.

Kebijakan moneter bertumpu pada hubungan antara suku bunga dalam perekonomian (yang merupakan harga peminjaman uang) dengan uang beredar untuk mempengaruhi tujuantujuan pembangunan ekonomi, seperti pengendalian harga (inflasi dan nilai tukar), pertumbuhan ekonomi, dan tingkat pengangguran. Hal ini dimungkinkan karena otoritas moneter suatu negara pada umumnya memiliki otoritas tunggal dalam mencetak dan mengedarkan uang resmi negara, sehingga otoritas moneter dapat mempengaruhi suku bunga dalam perekonomian melalui kemampuannya mengubah jumlah uang beredar untuk mencapai tujuan akhir kebijakan.

Terdapat berbagai jenis kebijakan moneter yang dalam pelaksanaannya sama-sama berusaha mempengaruhi uang primer ( $\mathrm{M} 0$ ) dalam peredaran melalui perdagangan instrument hutang atau kredit pemerintah pada operasi pasar terbuka. Perbedaan dari berbagai jenis kebijakan moneter terletak pada instrumen yang dipilih dan target antara yang dituju (lihat Tabel 1). Jenis kebijakan moneter yang bermacam-macam ini juga disebut rezim moneter.

\begin{tabular}{l|l|l|}
\multicolumn{1}{|c}{} & \multicolumn{2}{c}{ Tabel 1. } \\
\multicolumn{1}{|c|}{ Jenis-jenis Kebijakan Moneter } \\
Rezim Moneter & \multicolumn{1}{|c}{ Instrumen } & \multicolumn{1}{c}{ Target/Tujuan } \\
Inflation Targeting & Suku bunga overnight & Tingkat inflasi yang ditetapkan \\
Price Level Targeting & Suku bunga overnight & Tingkat inflasi tertentu \\
Monetary Aggregates & Pertumbuhan uang beredar & Tingkat inflasi yang ditetapkan \\
Fixed Exchange Rate & Nilai tukar spot & Nilai tukar spot \\
Gold Standard & Harga emas spot & $\begin{array}{l}\text { Inflasi rendah diukur dari harga emas } \\
\text { Tingkat pengangguran dan tingkat inflasi }\end{array}$ \\
Mixed Policy & Suku bunga & \\
Sumber: Wikipedia & &
\end{tabular}

Penerapan rezim moneter tertentu oleh suatu negara mengalami evolusi dari waktu ke waktu. Rezim gold standard, yang menetapkan nilai tukar mata uang nasional terhadap sejumlah emas, diterapkan secara luas di seluruh dunia sebelum tahun 1971 dan tidak lagi digunakan setelah runtuhnya kesepakatan Bretton Woods pada tahun 1971. Price level targeting, yang menetapkan tingkat inflasi setiap tahun dan mengoreksinya di tahun berikutnya sehingga tingkat harga tidak berubah dalam jangka panjang, pernah diterapkan Swedia pada tahun 1930an, namun sudah tidak lagi diterapkan oleh negara manapun sejak tahun 2004. Rezim monetary 
aggregates dari mazhab monetarist, yang berdasar pada pertumbuhan tetap uang beredar, banyak diterapkan di berbagai negara di tahun 1980an. Selain itu, rezim fixed exchange rate, yang berdasar pada penjagaan nilai tukar mata uang nasional terhadap mata uang asing secara tetap, diterapkan oleh banyak (sekitar 56) negara berkembang dan negara kecil dengan kadar yang berbeda-beda. Sedangkan mixed policy, yang berdasar pada Taylorrule yang meyakini bahwa suku bunga bereaksi terhadap goncangan dari inflasi dan output, diterapkan oleh Amerika sejak tahun 1980an.

Sementara itu, rezim inflation targeting, yang secara eksplisit menjaga tingkat inflasi tertentu (misalnya inflasi indeks harga konsumen) pada rentang tertentu, mulai populer sejak awal 1990an dan semakin banyak diadopsi oleh negara maju maupun negara berkembang saat ini.

\begin{tabular}{|c|c|c|c|}
\hline \multicolumn{4}{|c|}{$\begin{array}{c}\text { Tabel } 2 . \\
\text { Rezim Moneter di Beberapa Negara }\end{array}$} \\
\hline Negara & Rezim Moneter & Negara & Rezim Moneter \\
\hline Negara Maju & & Negara Berkembang & \\
\hline $\begin{array}{l}\text { United States } \\
\text { United Kingdom } \\
\text { Eurozone } \\
\text { Australia } \\
\text { New Zealand } \\
\text { Canada } \\
\text { Singapore }\end{array}$ & $\begin{array}{l}\text { Mixed Policy } \\
\text { Inflation Targeting, + target } \\
\text { sekunder output \& employment } \\
\text { Inflation Targeting } \\
\text { Inflation Targeting } \\
\text { Inflation Targeting } \\
\text { Inflation Targeting } \\
\text { Exchange Rate Targeting }\end{array}$ & $\begin{array}{l}\text { Indonesia } \\
\text { Malaysia } \\
\text { Thailand } \\
\text { India }\end{array}$ & $\begin{array}{l}\text { Inflation Targeting } \\
\\
\text { Inflation Targeting } \\
\text { Inflation Targeting } \\
\text { Inflation Targeting }\end{array}$ \\
\hline Amerika Latin & & Lainnya & \\
\hline $\begin{array}{l}\text { Brazil } \\
\text { Chile }\end{array}$ & $\begin{array}{l}\text { Inflation Targeting } \\
\text { Inflation Targeting }\end{array}$ & $\begin{array}{l}\text { Korea } \\
\text { Turkey } \\
\text { China } \\
\text { Hong Kong }\end{array}$ & $\begin{array}{l}\text { Inflation Targeting } \\
\text { Inflation Targeting } \\
\text { Monetary Targeting \& } \\
\text { target basket mata uang } \\
\text { Currency Board - fixed } \\
\text { terhadap US\$ }\end{array}$ \\
\hline
\end{tabular}

Inflation targeting adalah salah satu rezim keijakan moneter ketika bank sentral berusaha menjaga inflasi dalam rentang target yang diumumkan, biasanya dengan instrumen suku bunga kebijakan. Menurut Alamsyah dan Masyhuri (2000) inflation targeting pada dasarnya merupakan suatu kerangka kerja (framework) dalam kebijakan moneter yang berupaya untuk meniadakan bias inflasi dari pelaksanaan kebijakan moneter yang berdasarkan discretion tetapi dalam kerangka perencanaan sasaran inflasi ke depan yang transparan. Dengan sifatnya yang sedemikian itu inflation targeting merupakan cerminan dari constrained discretion dalam kebijakan moneter. 
Rezim moneter ini merupakan 'kompromi' antara aliran Klasik, yang berpendapat bahwa inflasi selalu merupakan fenomena moneter, sehingga kebijakan moneter harus mengikuti aturan secara ketat (rule), dengan aliran Keynesian, yang berpendapat bahwa inflasi bukan disebabkan karena jumlah uang yang melebihi jumlah barang, melainkan karena terlalu banyak pekerjaan mencari tenaga kerja melebihi jumlah dan kapasitas yang tersedia, sehingga kebijakan moneter bertugas untuk menjamin terjadinya keseimbangan antara sisi permintaan dan penawaran di dalam perekonomian dan oleh karenanya harus dilakukan secara bijaksana (discretion) sesuai dengan perkembangan yang ada. Komprominya, dalam jangka panjang kebijakan moneter mempunyai sasaran jangka menengah dan panjang mengikuti rule yang ditetapkan, sedangkan dalam jangka pendek kebijakan moneter memiliki discretion sesuai keadaan.

\subsection{Transmisi Kebijakan Moneter Konvensional}

Transmisi kebijakan moneter dari perspektif konvensional dapat melalui jalur suku bunga, jalur kredit, jalur nilai tukar, jalur harga aset, dan jalur ekspektasi. Dengan digunakannya instrument suku bunga dalam rezim moneter inflation targeting, transmisi kebijakan moneter melalui jalur suku bunga (interest rate pass-through) menjadi salah satu topik bahasan penting.

Model interest rate pass-through telah dikembangkan sejak lama, seperti model yang dikembangkan oleh Rousseas (1985) yang disebut model marginal cost pricing yang menyatakan bahwa perubahan suku bunga cost of funds bank akan diteruskan dalam bentuk perubahan suku bunga bank kepada nasabahnya, karena hal ini mencerminkan perubahan marginalcost dari bank. Model ini masih dianggap sebagai model terbaik untuk menjelaskan interest rate pass-through dari suku bunga kebijakan ke suku bunga perbankan (Egert et al., 2006). Persamaan umumnya adalah sebagai berikut.

$$
b r_{n, t}=\gamma_{0}+\gamma m r_{n, t}
$$

Dimana $b r$ adalah suku bunga yang ditetapkan bank, $\gamma_{0}$ adalah markup, dan $m r$ adalah marginal cost price yang di-proxy dengan market interest rate. Ide dasar dari persamaan diatas adalah market interest rate dapat menggambarkan marginal cost price karena market rate merupakan marginal funding cost yang dihadapi bank.

Beberapa faktor yang dapat menjelaskan spread antara suku bunga ritel dan marginal cost of fund, antara lain tingkat kompetisi (semakin tinggi kompetisi, semakin rendah spread), perbedaan suku bunga bagi nasabah berbeda, dan asymmetric information antara peminjam dan pemberi pinjaman. Faktor-faktor ini juga yang menurut Bredin (2002) dapat mempengaruhi tingkat dan kecepatan pass-through dari suku bunga kebijakan ke suku bunga perbankan yang secara umum dapat dibagi tiga, yaitu: 1) kebjakan moneter; 2) tingkat kompetisi perbankan; dan 3) faktor-faktor lain. 
Dalam kajian empiris interest rate pass-through ada yang menggunakan standard single equation error correction model (ECM), seperti yang dilakukan Mojon (2000), Bredin (2001), de Bondt (2002), Espinosa-Vega dan Rebucci (2003), Chmielewski (2004), Tieman (2004), Horvath et al. (2005), Betancourt et al. (2008), dan van Leuvensteijn et al. (2008). Sedangkan persamaan estimasinya, seperti yang dikemukakan de Bondt (2002), adalah sebagai berikut.

$$
\Delta b r_{n, t}=\eta_{n}+\alpha \Delta m r_{t}-\beta\left(b r_{n, t-1}-\gamma m r_{t-1}\right)+\varepsilon_{n, t}
$$

Diman $\alpha$ adalah parameter pass-through satu periode, sedangkan $\beta$ adalah parameter kecepatan penyesuaian pass-through. Estimasi dilakukan dalam dua tahap, sehingga metode ini disebut juga two-step ECM. Tahap pertama adalah menghitung residual dari Persamaan $1\left(\mathrm{br} r_{n, t-1}-\gamma m r_{t-1}\right)$. Tahap kedua mengestimasi Persamaan 2 dengan memasukkan residual $\left(b r_{n, t-1}-\gamma m r_{t-1}\right)$.

Standard ECM kemudian dikembangkan untuk non-linear atau asymmetric ECM, seperti yang dilakukan Scholnick (1999), Chmielewski (2004), sehingga Persamaan 2 menjadi seperti yang dikemukakan Scholnick (1999), sebagai berikut.

$$
\Delta b r_{n, t}=\eta_{n}+\alpha \Delta m r_{t}+\beta_{1} e c t_{n, t-1}^{+}+\beta_{2} e c t_{n, t-1}^{-}+\varepsilon_{n, t}
$$

Dimana $\beta 1$ adalah tingkat penyesuaian positif pada $t$ tertentu, sedangkan $\beta 2$ adalah tingkat penyesuaian negatif pada $t$ tertentu.

Standard ECM juga dikembangkan dalam bentuk extended ECM untuk dapat mendeteksi 'complete' atau 'incomplete'-nya' pass-through, seperti yang dilakukan Weth (2002), Chmielewski (2004), sehingga Persamaan 2 menjadi seperti yang dikemukakan Weth (2002), sebagai berikut.

$$
\Delta b r_{n, t}=\eta_{n}+\alpha \Delta m r_{t}+\beta\left(b r_{n, t-1}-m r_{t-1}\right)+\delta b r_{n, t-1}+\varepsilon_{n, t}
$$

Dimana $\delta$ menunjukkan incomplete pass-through jika $\neq 0$.

Versi lain ECM adalah metode auto regressive distributed lag (ARDL), seperti yang dilakukan Crespo-Cuaresma et al. (2004), Burgstaller (2005), Liu et al. (2005), Egert et al. (2006), Marotta (2007), sehingga Persamaan 2 menjadi seperti yang dikemukakan Cuaresma et al. (2004), sebagai berkut.

$$
\Delta b r_{t}=\delta_{0}+\sum_{j=1}^{p-1} \mu_{j} \Delta b r_{t-j}+\sum_{k=0}^{q} \kappa_{k} \Delta m r_{t-k}+\gamma\left(b r_{t-1}-\lambda m r_{t-1}\right)+\varepsilon_{t}
$$


Dimana, $\gamma$ adalah speed of adjustment dan $\lambda$ adalah multiplier (pass-through) jangka panjang.

Pengembangan lain dari standard ECM, antara lain model dynamic ordinary least square atau DOLS, model threshold autoregressive atau TAR (Horvath et al., 2005), model transfer function approach (Qayyum et al., 2005), model dynamic seemingly unrelated regression atau DSUR (Sorensen dan Werner, 2006), dan model panel ARDL (Aydin, 2007).

Penelitian empiris penelitian tentang transmisi kebijakan moneter dalam perspektif konvensional, khususnya tentang interest rate pass-through, sudah banyak dilakukan. EspinosaVega dan Rebucci (2003) membandingkan Chile dan negara lain (Euro, Canada, US, Australia dan New Zealand), Egert et al. (2006) menggunakan sampel lima negara Eropa Tengah dan Timur atau CEE-5 (Czech Republic, Hungary, Poland, Slovakia, dan Slovenia), sedangkan Sorensen dan Werner (2006) menggunakan sampel negara-negara Euro area dengan panel data dinamis dan metode ECM. Egert et al. (2006) menemukan bahwa interest rate pass-through di CEE-5 rendah dan menurun dari tahun ke tahun karena tidak adanya kointegrasi antara suku bunga kebijakan dengan suku bunga perbankan (jangka pendek dan jangka panjang), serta diperkirakan akan terus menurun di masa yang akan datang. Sedangkan Sorensen dan Werner (2006) menemukan heterogenitas yang besar di negara-negara Euro area tentang keseimbangan passthrough jangka panjang dan kecepatan penyesuaiannya. Hasil ini juga mengkonfirmasi lambat dan tidak komplitnya proses penyesuaian suku bunga perbankan terhadap suku bunga kebijakan.

Horvath et al. (2005) menemukan suku bunga kredit korporasi menyesuaikan dengan cepat dan komplit, sedangkan suku bunga deposito dan kredit rumahtangga menyesuaikan dengan lambat dan tidak komplit, terhadap perubahan suku bunga kebijakan. Qayyum et al. (2005) menemukan pass-through dari suku bunga kebijakan (T-Bills rate) ke call money rate komplit dalam satu bulan, sedangkan pass-through dari suku bunga kebijakan ke suku bunga simpanan dan pinjaman perbankan memakan waktu lebih lama. Liu et al. (2005) menyimpulkan adanya complete pass-through jangka panjang untuk beberapa suku bunga perbankan di New Zealand, dan secara keseluruhan mengkonfirmasi bahwa suku bunga kebijakan lebih berpengaruh terhadap suku bunga jangka pendek dan peningkatan transparansi meningkatkan efektivitas kebijakan moneter.

Penelitian-penelitian terbaru menghubungkan interest rate pass-through suku bunga kebijakan ke suku bunga perbankan dengan penerapan Euro (Marotta, 2007), dengan variabelvariabel ekonomi makro yang juga mempengaruhi suku bunga perbankan (Betancourt et al., 2008), dengan kebijakan moneter optimal (Kobayashi, 2008), dengan kompetisi antarbank (Van Leuvensteijn et al., 2008).

Marotta (2007) meneliti structural breaks pada interest rate pass-through dari suku bunga kebijakan ke suku bunga pinjaman perbankan dan proses penyatuan euro. Hasilnya menunjukkan bahwa negara-negara anggota EU memiliki kecepatan penyesuaian berbeda-beda terhadap unifikasi Euro pada Januari 1999, dan mereka menyesuaikan rezim moneter baru secara perlahan- 
lahan. Ditemukan bahwa interest rate pass-through negara-negara EU bersifat incomplete yang berarti bahwa kebijakan moneter tunggal berkurang efektivitasnya. Hasil ini berlawanan dengan intuisi ekonomi bahwa penurunan volatilitas suku bunga kebijakan (money market rate) akan memperlancar transfer suku bunga kebijakan ke suku bunga perbankan.

Betancourt et al. (2008) melakukan penelitian interest rate pass-through di Colombia dalam perspektif micro banking dengan data bulanan periode 1999-2006, dengan menggunakan metode single equation error correction model (EC) dan vector autoregressive model(VARX). Hal ini dilandasi pada teori ekonomi mikro bahwa pengaruh suku bunga kebijakan terhadap suku bunga Perbankan merupakan proses yang rumit yang bergantung juga pada variabel-variabel ekonomi makro yang menunjukkan keadaan ekonomi suatu Negara. Hasilnya dari ke dua model mendukung hipotesis bahwa, selain suku bunga kebijakan, variable-variabel makro ekonomi juga mempengaruhi mekanisme transmisi kebijakan moneter ke suku bunga Perbankan. Selain itu, hasil model EC menunjukkan incomplete pass-through, sedangkan hasil model VARX menunjukkan complete pass-through.

Kobayashi (2008) membahas incomplete interest-rate pass-through di Euro area dan bagaimana kebijakan moneter yang optimal. Dia menyatakan bahwa jika tidak semua bank komersial langsung merespon perubahan suku bunga kebijakan, maka kebijakan moneter tidak akan memberikan dampak yang sama terhadap keseluruhan ekonomi. Hasilnya menunjukkan bahwa jika hanya sebagian dari suku bunga pinjaman Perbankan yang disesuaikan dengan adanya perubahan suku bunga kebijakan, fluktuasi rata-rata suku bunga pinjaman menimbulkan biaya welfare, sehingga bank sentral perlu melakukan stabilisasi perubahan suku bunga pinjaman dengan cara policy rate smoothing. Namun, perubahan drastis suku bunga kebijakan tetap diperlukan ketika terdapat shock yang secara langsung mempengaruhi suku bunga pinjaman.

Van Leuvensteijn et al. (2008) melakukan studi tentang dampak kompetisi bank pada interest rate pass-through di Euro area selama periode 1994-2004 dengan dua tahap. Tahap pertama mengukur tingkat kompetisi dengan metode Boone indicator. Tahap kedua mengukur pengaruh kompetisi terhadap interest rate pass-through dari suku bunga kebijakan ke suku bunga Perbankan dengan metode panelerror correction model (ECM). Hasil tahap pertama menunjukkan bahwa kompetisi yang semakin ketat membuat spread antara suku bunga kebijakan (market rate) dan suku bunga perbankan, khususnya kredit, semakin kecil. Hasil tahap kedua menunjukkan bahwa semakin tinggi tingkat kompetisi perbankan di suatu negara, bank semakin menetapkan suku bunga kreditnya sesuai dengan suku bunga kebijakan. Selain itu, tekanan kompetisi lebih berat di pinjaman dari pada di simpanan. Suku bunga perbankan pada pasar yang lebih kompetitif merespon lebih kuat terhadap perubahan suku bunga kebijakan. Implikasinya adalah ketentuan untuk meningkatkan persaingan Perbankan akan meningkatkan efektivitas (kekuatan dan kecepatan) mekanisme transmisi kebijakan moneter. 


\begin{tabular}{|c|c|c|c|c|c|c|c|c|}
\hline \multicolumn{9}{|c|}{$\begin{array}{c}\text { Tabel } 3 . \\
\text { Interest Rate Pass-Through dengan Standard ECM di Beberapa Negara }\end{array}$} \\
\hline \multirow{2}{*}{ Penulis } & \multirow{2}{*}{ Negara } & \multicolumn{2}{|c|}{ Jangka Pendek } & \multicolumn{2}{|c|}{ Jangka Panjang } & \multirow{2}{*}{ Penyesuaian } & \multicolumn{2}{|c|}{ Kererangan } \\
\hline & & Simpanan & Pinjaman & Simpanan & Pinjaman & & Pdk & $\mathrm{Pj}$ \\
\hline $\begin{array}{l}\text { Bredin et al. } \\
2001\end{array}$ & Ireland & & & & $0.64-0.88$ & $0.25-0.72$ & Str Break & \\
\hline $\begin{array}{l}\text { De Bondt } \\
2002\end{array}$ & Euro area & $0.32-0.35$ & $0.13-0.54$ & $0.35-0.98$ & $0.92-1.53$ & $\begin{array}{l}\text { S 3-15 bln } \\
\text { P 3-10 bln }\end{array}$ & $\begin{array}{l}\mathrm{S} \approx \mathrm{P} \\
\mathrm{Pdk}<\mathrm{Pjg}\end{array}$ & $\mathrm{S}<\mathrm{P}$ \\
\hline \multirow{6}{*}{$\begin{array}{l}\text { Espinosa- } \\
\text { Vega \& } \\
\text { Rebucci } 2003\end{array}$} & Chile & $0.20-0.68$ & $0.18-0.63$ & $0.39-0.68$ & $0.55-0.88$ & $\begin{array}{l}\text { S 1/2-4 bln } \\
\text { P 2/3-2 bln }\end{array}$ & $\begin{array}{l}\mathrm{S} \approx \mathrm{P} \\
\mathrm{Pdk}<\mathrm{Pjg}\end{array}$ & $\mathrm{S}<\mathrm{P}$ \\
\hline & Euro & $0.27-0.57$ & $0.18-0.43$ & $0.60-0.72$ & $0.57-0.82$ & $\begin{array}{l}\text { S } 11 / 2-17 \text { bln } \\
\text { P 3-11 bln }\end{array}$ & $\begin{array}{l}\mathrm{S}>\mathrm{P} \\
\mathrm{Pdk}<\mathrm{Pjg}\end{array}$ & $S>P$ \\
\hline & Canada & $1.05-1.13$ & $0.46-0.83$ & $0.93-0.98$ & $0.24-1.01$ & $\begin{array}{l}\mathrm{S} \approx 0 \mathrm{bln} \\
\mathrm{P}_{-}-4 \mathrm{bln}\end{array}$ & $\begin{array}{l}\mathrm{S}>\mathrm{P} \\
\mathrm{Pdk} \approx \mathrm{Pjg}\end{array}$ & $S>P$ \\
\hline & US & $0.84-1.00$ & 0.86 & $0.64-1.00$ & 1.00 & $\begin{array}{l}\text { S } 0-2 \text { bln } \\
\text { P } 0.2 \text { bln }\end{array}$ & $\begin{array}{l}S \approx P \\
P d k \approx P j g\end{array}$ & $\mathrm{~S}<\mathrm{P}$ \\
\hline & Australia & $0.40-0.87$ & 0.46 & $0.67-0.81$ & 1.09 & $\begin{array}{l}S_{1}-1.4 \mathrm{bln} \\
\mathrm{P} 3.86 \mathrm{bln}\end{array}$ & $\begin{array}{l}\mathrm{S} \approx \mathrm{P} \\
\mathrm{Pdk}<\mathrm{Pjg}\end{array}$ & $\mathrm{S}<\mathrm{P}$ \\
\hline & $\begin{array}{l}\text { New } \\
\text { Zealand }\end{array}$ & $0.34-0.42$ & 0.21 & $0.71-0.74$ & 0.77 & $\begin{array}{l}\text { S 2-2_ bln } \\
\text { P } 2 \text { bln }\end{array}$ & $\begin{array}{l}\mathrm{S}>\mathrm{P} \\
\mathrm{Pdk}<\mathrm{Pjg}\end{array}$ & $\mathrm{S} \approx \mathrm{P}$ \\
\hline $\begin{array}{l}\text { Chmielewski } \\
2004\end{array}$ & Polandia & $0.22-0.57$ & $0.47-0.68$ & $0.75-0.88$ & $0.85-1.02$ & $\begin{array}{l}\text { S 1-4 bln } \\
\text { P 1_-5 bln }\end{array}$ & $\begin{array}{l}\mathrm{S}<\mathrm{P} \\
\mathrm{Pdk}<\mathrm{Pjg}\end{array}$ & $\mathrm{S}<\mathrm{P}$ \\
\hline \multirow{6}{*}{ Tieman 2004} & Czech & $0.09-0.02$ & $0.07 \quad 0.19$ & 0.800 .49 & 0.760 .65 & $\begin{array}{l}\mathrm{S} 1{ }_{-} 8.1 \mathrm{bln} \\
\mathrm{P} 2.4 \quad 4.4 \mathrm{bln}\end{array}$ & $\begin{array}{l}\mathrm{S} \approx \mathrm{P} \\
\mathrm{Pdk}<\mathrm{Pjg}\end{array}$ & $\mathrm{S} \approx \mathrm{P}$ \\
\hline & Hungary & 0.220 .07 & $-0.15 \quad 0.01$ & 0.820 .90 & 1.100 .67 & $\begin{array}{l}\text { S } 1.62 .8 \text { bln } \\
\text { P 10_9_ bln }\end{array}$ & $\begin{array}{l}\mathrm{S} \neq \mathrm{P} \\
\mathrm{Pdk}<\mathrm{Pjg}\end{array}$ & $\mathrm{S} \approx \mathrm{P}$ \\
\hline & Polandia & 0.290 .23 & 0.180 .10 & 0.980 .91 & 0.850 .96 & $\begin{array}{l}\mathrm{S} 36.82 \mathrm{bln} \\
\text { P } 6.410 \mathrm{bln}\end{array}$ & $\begin{array}{l}\mathrm{S}>\mathrm{P} \\
\mathrm{Pdk}<\mathrm{Pjg}\end{array}$ & $\mathrm{S} \approx \mathrm{P}$ \\
\hline & Romania & $\ldots .-0.30$ & $-0.46-044$ & $\ldots \ldots-0.78$ & $0.80 \quad 0.73$ & $\begin{array}{l}\text { S ..... 5_ bln } \\
\text { P 3_ } 4 \text { bln }\end{array}$ & $\begin{array}{l}\mathrm{S} \approx \mathrm{P} \\
\mathrm{Pdk}<\mathrm{Pjg}\end{array}$ & $S \approx P$ \\
\hline & Slovak & $0.04 \quad 0.23$ & -0.020 .07 & 1.001 .27 & 1.620 .79 & $\begin{array}{l}\text { S } 6.922 \text { bln } \\
\text { P 9_ } 5.8 \mathrm{bln}\end{array}$ & $\begin{array}{l}\mathrm{S}>\mathrm{P} \\
\mathrm{Pdk}<\mathrm{Pjg}\end{array}$ & $\mathrm{S} \approx \mathrm{P}$ \\
\hline & Slovenia & 0.160 .11 & 0.160 .15 & 1.411 .57 & 2.081 .85 & $\begin{array}{l}\text { S 5_6_ bln } \\
\text { P } 11.2 \text { 9_bln }\end{array}$ & $\begin{array}{l}\mathrm{S} \approx \mathrm{P} \\
\mathrm{Pdk}<\mathrm{Pjg}\end{array}$ & $S \approx P$ \\
\hline $\begin{array}{l}\text { Horvath et al. } \\
2005\end{array}$ & Hungary & 0.410 .64 & 0.050 .67 & 0.860 .87 & 0.810 .98 & $\begin{array}{l}\text { S } 3-2 \text { bln } \\
\text { P } 4-2 \text { bln }\end{array}$ & $\begin{array}{l}\mathrm{S} \approx \mathrm{P} \\
\mathrm{Pdk}<\mathrm{Pjg}\end{array}$ & $S \approx P$ \\
\hline
\end{tabular}

Note: S simpanan; P pinjaman; bln bulan; Pdk jangka pendek; Pjg jangka panjang. 
Hasil interest rate pass-through dengan metode standard ECM untuk beberapa negara dapat dibaca pada Tabel 3. Secara keseluruhan, hasil IRPT tidak seragam dari satu negara dengan negara lain. Satu benang merah yang menunjukkan kesamaan interest rate pass-through antar negara adalah bahwa tingkat pass-through jangka pendek lebih kecil dari pada tingkat pass-through jangka panjang, kecuali untuk US dimana tingkat pass-through jangka pendek sama dengan tingkat pass-through jangka panjang. Sedangkan tingkat pass-through antara simpanan dan pinjaman sangat bervariasi. Pada sebagian negara, tingkat pass-through simpanan lebih kecil dari pada tingkat pass-through pinjaman. Pada sebagian negara yang lain terjadi hal yang sebaliknya, dimana tingkat pass-through simpanan lebih besar dari pada tingkat passthrough pinjaman. Sedangkan pada sebagian negara yang lain lagi, tingkat pass-through simpanan sama dengan tingkat pass-through pinjaman. Sehingga, dalam hal ini tidak dapat diambil kesimpulan umum. Demikian juga halnya dengan speed of adjustment atau kecepatan penyesuaian dari interest rate pass-through yang bervariasi antar negara.

Tabel 4 memberikan gambaran bervariasinya tingkat pass-through simpanan dan pinjaman antar negara. Namun demikian, secara umum terdapat pola tertentu. Dalam jangka pendek, tingkat pass-through simpanan sama dengan atau lebih besar dari tingkat pass-through pinjaman. Dalam jangka panjang, tingkat pass-through simpanan sama dengan atau lebih kecil dari tingkat pass-through pinjaman. Dan, sebagian besar kajian empiris menunjukkan bahwa tingkat pass-through simpanan sama dengan tingkat pass-through pinjaman dalam jangka pendek maupun jangka panjang.

\begin{tabular}{|c|c|c|}
\hline \multicolumn{3}{|c|}{$\begin{array}{l}\text { Tabel } 4 . \\
\text { Interest Rate Pass-Through dengan Standard ECM di Beberapa Negara }\end{array}$} \\
\hline Simpanan $<$ Pinjaman & Simpanan $\approx$ Pinjaman & Simpanan $>$ Pinjaman \\
\hline Chile (Pjg) & Chile (Pdk) & \\
\hline \multirow[t]{2}{*}{ Euro area $(P j g)$} & Euro area (Pdk) & Euro (Pdk, Pjg) \\
\hline & & Canada (Pdk, Pjg) \\
\hline US (Pjg) & US (Pdk) & \\
\hline \multirow[t]{3}{*}{ Australia (Pjg) } & Australia (Pdk) & \\
\hline & New Zealand (Pjg) & New Zealand (Pdk) \\
\hline & Czech (Pdk, Pjg) & \\
\hline \multirow[t]{5}{*}{ Polandia (Pdk, Pjg) } & Polandia (Pjg) & Polandia (Pdk) \\
\hline & Romania (Pdk, Pjg) & \\
\hline & Slovak (Pjg) & Slovak (Pdk) \\
\hline & Hungary (Pdk, Pjg) & \\
\hline & Slovenia (Pdk, Pjg) & \\
\hline
\end{tabular}




\subsection{Transmisi Kebijakan Moneter Islam}

Transmisi kebijakan moneter muncul sejak munculnya otoritas moneter yang terpisah dari otoritas fiskal. Otoritas moneter berkembang sejalan dengan berkembangnya bank sentral dari bank sirkulasi (menerbitkan uang kertas atau fiat money) yang ditandai dengan munculnya Bank of England (BOE) pada tahun 1694 (Capie, 1994). Karena uang kertas sifatnya inflatoir (karena tidak memiliki nilai intrinsic) maka tugas bank sentral berkembang termasuk mengatur jumlah uang yang beredar untuk mengendalikan nilai mata uang atau inflasi. Hal ini tidak diperlukan ketika uang yang digunakan adalah uang intrinsic, seperti Dinar emas dan Dirham perak di masa masih adanya kekhalifahan Islam. Khilafah Islamiyah terakhir, yaitu Dinasti Utsmaniyah di Turki, runtuh pada tahun 1924 (Islahi, 2004).

Di masa dominasi ekonomi konvensional dengan uang kertas dan bank sentralnya sampai saat ini, ekonomi Islam berkembang di Negara-negara berpenduduk mayoritas Muslim di tengah system uang kertas dan bank sentral. Oleh karena itu, berkembang pula system moneter Islam dengan kebijakannya dan proses transmisinya.Salah satu pionir pengembang teori ekonomi moneter Islam kontemporer adalah Muhammad Umer Chapra dengan bukunya 'Towards a Just Monetary System' (1985).

Setting institusi keuangan Islam kontemporer tidak jauh berbeda dengan setting institusi keuangan konvensional yang sudah established, sehingga instrument-instrumen kebijakan moneter Islam juga banyak yang mirip dengan instrument-instrumen kebijakan moneter konvensional. Namun, karena cara kerja instrument kebijakan moneter Islam memiliki persamaan dan perbedaan prinsip dengan cara kerja instrument kebijakan moneter konvensional, transmisi kebijakan moneter Islam dapat sama atau berbeda dengan transmisi kebijakan moneter konvensional. Chapra (1985) tidak mendiskusikan secara spesifik masalah transmisi kebijakan moneter Islam ini. Perkembangan teori moneter Islam selanjutnya juga belum ada yang menyinggung tentang transmisi kebijakan moneter Islam, termasuk pass-through atau jalurjalurnya (lihat Siddiqui, 2007).

Namun demikian, beberapa studi empiris mulai bermunculan untuk melihat adanya transmisi kebijakan moneter Islam dengan karakteristiknya. Sukmana dan Kassim (2010) merupakan upaya awal untuk mengetahui adanya transmisi kebijakan moneter pada jalur pembiayaan melalui perbankan Syariah Malaysia ke pertumbuhan ekonomi, yang dirumuskan secara sederhana sebagai berikut.

$$
I P I=f(I F, I D, O N I G H T)
$$

Dimana IPI adalah Industrial production index sebagai proksi pertumbuhan ekonomi atau output, IF adalah pembiayaan perbankan Syariah, ID adalah pendanaan atau dana pihak ketiga/DPK perbankan Syariah, dan ONIGHT adalah suku bunga overnight di pasar uang antarbank sebagai indicator kebijakan moneter. 
Hal yang sama untuk kasus Indonesia telah dilakukan oleh Ascarya (2010) dengan tujuan untuk mengetahui adanya transmisi kebijakan moneter pada jalur pembiayaan melalui perbankan Syariah Indonesia ke tujuan akhir kebijakan moneter, yaitu pertumbuhan ekonomi dan kestabilan nilai uang, yang dirumuskan secara sederhana sebagai berikut.

$$
I P I=f(I F I N, I D E P, P U A S, S B I S)
$$

Dan

$$
C P I=f(I F I N, I D E P, P U A S, S B I S)
$$

Dimana IPI adalah Industrial production index sebagai proksi pertumbuhan ekonomi atau output, CPI adalah Consumer price index sebagai proksi inflasi, IFIN adalah pembiayaan perbankan Syariah, IDEP adalah pendanaan atau dana pihak ketiga/DPK perbankan Syariah, dan PUAS adalah suku bunga satu hari di pasar uang antar bank Syariah, dan SBIS adalah imbal hasil Sertifikat Bank Indonesia Syariah sebagai indikator kebijakan moneter.

Selain itu, Ayuniyyah, et al. (2010) meneliti transmisi kebijakan moneter ganda di Indonesia dalam rangka mencapai tujuan pertumbuhan ekonomi, yang dapat dirumuskan secara sederhana sebagai berikut.

$$
I P I=f(n I F I N, n C C R D, i I F I N, i C C R D, n I D E P, n C D E P, i I D E P, i C D E P, S B I S, S B I)
$$

Dimana IPI adalah Industrial production index sebagai proksi pertumbuhan ekonomi atau output, nIFIN adalah jumlah pembiayaan perbankan Syariah, nCCRD adalah jumlah kredit perbankan konvensional, ilFIN adalah imbal hasil pembiayaan perbankan Syariah, iCCRD adalah suku bunga kredit perbankan konvensional, nIDEP adalah jumlah pendanaan atau dana pihak ketiga/DPK perbankan Syariah, nCDEP adalah jumlah pendanaan atau DPK perbankan konvensional, iIDEP adalah imbal hasil DPK perbankan Syariah, iCDEP adalah imbal hasil DPK perbankan konvensional, SBIS adalah imbal hasil Sertifikat Bank Indonesia Syariah sebagai indikator kebijakan moneter Syariah, dan SBI adalah suku bunga Sertifikat Bank Indonesia sebagai indikator kebijakan moneter konvensional.

Sementara itu, policy rate pass-through Syariah belum pernah dikaji secara teoritis maupun empirik, untuk melihat efektivitas kebijakan moneter Syariah. Dengan kenyataan ini, efektivitas policy rate pass-through Syariah, untuk sementara dapat mengadopsi teori interest rate passthrough konvensional, dengan modifikasi yang setara.

Sebagai awalan, model interest rate pass-through konvensional (Egert et al., 2006) dapat dimodifikasi untuk membuat model policyratepass-through Syariah. Persamaan awal (1) 
dimodifikasi menjadi sebagai berikut.

$$
i b r_{n, t}=\gamma_{0}+\gamma i m r_{n, t}
$$

Dimana $i b r$ adalah imbal hasil (pendanaan atau pembiayaan) yang ditetapkan bank Syariah, $\gamma_{0}$ adalah markup, dan imr adalah marginal cost price yang di-proxy dengan market return.

Sedangkan persamaan estimasinya, dapat mengikuti de Bondt (2002) dengan modifikasi, sehingga menjadi sebagai berikut.

$$
\Delta i b r_{n, t}=\eta_{n}+\alpha \Delta i m r_{t}-\beta\left(i b r_{n, t-1}-\gamma i m r_{t-1}\right)+\varepsilon_{n, t}
$$

Dimana $\alpha$ adalah parameter pass-through satu periode, sedangkan $\beta$ adalah parameter kecepatan penyesuaian pass-through. Tahap pertama adalah menghitung residual dari Persamaan $10\left(\mathrm{ibr}_{n, t-1}-\mathrm{yimr}_{\mathrm{t}-1}\right)$. Tahap kedua mengestimasi Persamaan 11 dengan memasukkan residual $\left(i b r_{n, t-1}-\right.$ yimr $\left._{t-1}\right)$.

\section{METODOLOGI}

Paper ini menggunakan pendekatan kuantiatif dalam menganalisis kebijakan moneter dalam system keuangan ganda; konvensional dan Islam. Model empiris yang dibangung, mengacu pada kerangka konseptual sebagaimana tergambar pada Diagram 1.

Kebijakan moneter ganda di Indonesia menggunakan instrumen kebijakan moneter ganda, yaitu Surat Berharga Bank Indonesia atau SBI berbasis suku bunga untuk konvensional dan SBI Syariah atau SBIS berbasis fee untuk syariah yang masih merujuk kepada tingkat suku bunga SBI. Tingkat suku bunga SBI dan tingkat fee SBIS berperan sebagai policy rate. Policy rate ini akan mempengaruhi pendanaan dan pembiayaan perbankan melalui pasar uang antarbank konvensional dan syariah yang akan mempengaruhi biaya dana perbankan dalam menyalurkan kredit atau pembiayaannya. Expansi kredit dan pembiayaan akan menghasilkan output dan mempengaruhi tingkat inflasi.

\subsection{Data dan Variabel}

Data yang digunakan dalam studi ini adalah data sekunder runtut waktu (timeseries) bulanan dari suku bunga kebijakan moneter konvensional, suku bunga simpanan, dan pinjaman perbankan konvensional, serta bagi hasil/margin/fee kebijakan moneter syariah, bagi hasil simpanan/investasi dan bagi hasil/margin pembiayaan perbankan syariah, ditambah data inflasi IHK periode Januari 2003 sampai dengan September 2009, yang diperoleh dari SEKI,DSM, dan DPbS Bank Indonesia. 


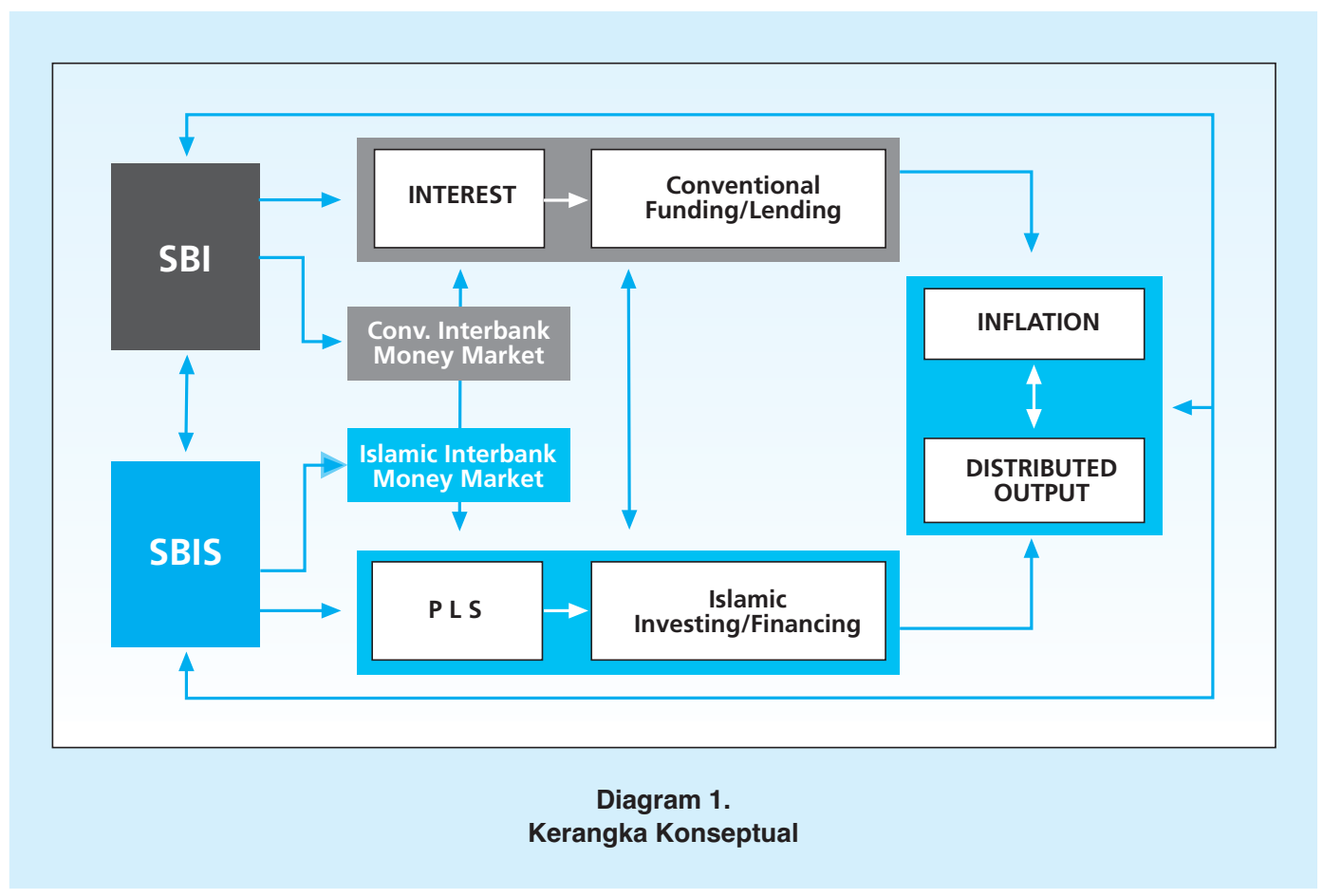

Variabel-variabel yang digunakan dalam menjawab pertanyaan penelitian pertama adalah sebagai berikut.

a. $\mathrm{SBI}_{\mathrm{t}}$ : Policy Rate konvensional, merupakan SBI 1 bulan yang didapat dari DSM-BI.

b. SBIS $_{t}$ : Policy Rate syariah, merupakan tingkat bonus SWBI dan tingkat fee SBIS (sejak April 2008) yang didapat dari Statistik Perbankan Syariah BI dan DSM-BI.

c. PUAB ${ }_{t}$ : Suku bunga pasar uang antarbank konvensional, didapat dari DSM-BI.

d. PUAS ${ }_{t}$ : Tingkat bagi hasil pasar uang antarbank syariah, didapat dari DSM-BI.

e. INT $t_{t}$ : Suku bunga kredit (modal kerja) bank konvensional, didapat dari DSM-BI.

f. PLS $_{\mathrm{t}}$ : Tingkat bagi hasil pembiayaan (Mudharabah + Musyarakah) bank syariah, didapat dari Direktorat Perbankan Syariah BI.

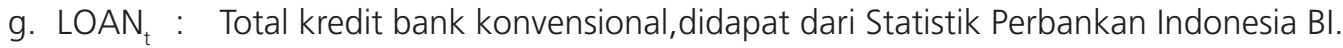

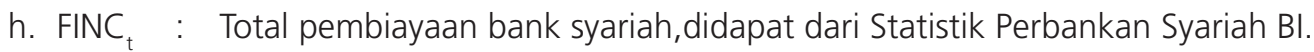

i. IHK $K_{t}$ : Tingkat inflasi yang didapat dari SEKI BI.

\subsection{Teknik Estimasi}

Penelitian ini akan menggunakan beberapa metode, yaitu Granger Causality dan Vector Autoregression (VAR) / Vector Error Correction Model (VECM) untuk tujuan (1), standard Error Correction Model dengan dua step untuk tujuan(2), serta deskriptif analitis untuk tujuan (3). 
Pertanyaan penelitian pertama untuk mengidentifikasi alur transmisi kebijakan moneter ganda di Indonesia melalui jalur konvensional suku bunga dan melalui jalur syariah bagi hasil/ margin/fee dan keterkaitan keduanya, pertama-tama akan dilakukan studi kausalitas dengan metode Granger Causality.Hubungan kausalitas antara variabel yang diuji merunut pada kerangka konseptual sebagaimana digambarkan berikut ini.

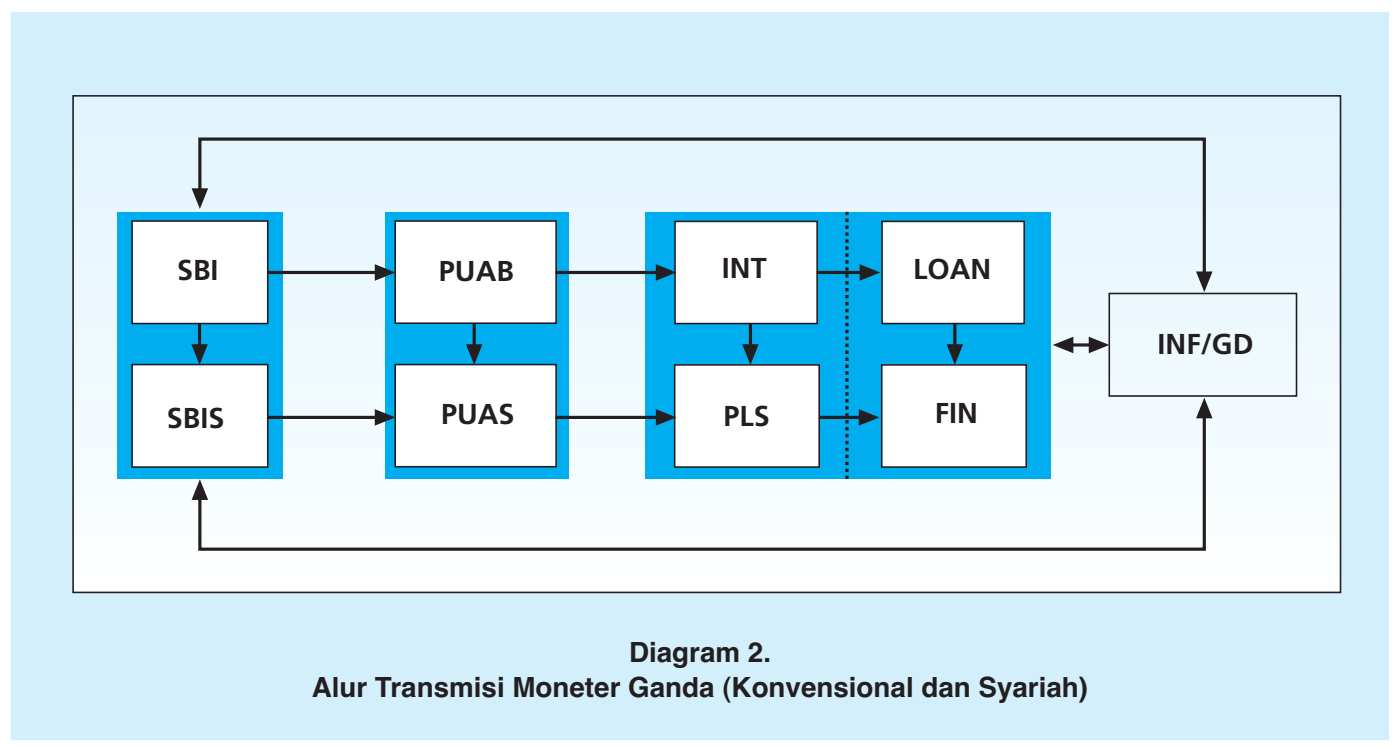

Pertanyaan penelitian kedua dapat dijawab dengan menggunakan Vector Auto Regression (VAR), dan jika terdapat kointegrasi maka teknik yang dgunakan akan berkembang ke Vector Error Correction Model (VECM). VAR merupakan system $n$ persamaan dengan jumlah variable endogen sebanyak $n$, dimana masing-masing variable dijelaskan oleh lag nya sendiri, nilai-nilai masa kini dan masa lalu variable edogen lainnya di dalam model. Oleh karena itu, dalam konteks ekonometri modern, VAR dianggap sebagai multivariate time-series yang membahas semua variabel endogen, karena tidak ada kepastian bahwa variabel sebenarnya eksogen, dan VAR sepenuhnya bertumpu pada data untuk menceritakan apa yang sebenarnya terjadi. Sims (1980) berpendapat bahwa jika ada simultanitas yang benar antar sejumlah variabel, maka variabelvariabel itu harus diperlakukan berdasarkan pijakan yang sama dan tidak boleh ada perbedaan a priori antara variabel endogen dan eksogen. Enders (2004) memformulasikan sistem firstorder bivariate primitive yang sederhana yang dapat ditulis, sebagai berikut:

$$
\begin{aligned}
& y_{t}=b_{10}-b_{12} z_{t}+\gamma_{11} y_{t-1}+\gamma_{12} z_{t-1}+\varepsilon_{y t} \\
& z_{t}=b_{20}-b_{21} y_{t}+\gamma_{21} y_{t-1}+\gamma_{22} z_{t-1}+\varepsilon_{z t}
\end{aligned}
$$


Dengan asumsi bahwa $y_{t}$ dan $z_{t}$ adalah stasioner, $\varepsilon_{y t}$ dan $\varepsilon_{z t}$ adalah white noise disturbances dengan standar deviasi $\sigma_{y}$ dan $\sigma_{z}$, dan $\varepsilon_{y t}$ and $\varepsilon_{z t}$ adalah white noise disturbance yang tidak terkorelasi. Sementara itu, bentuk standar dari bentuk primitive di atas dapat ditulis sebagai berikut.

$$
\begin{aligned}
& y_{t}=a_{10}+a_{11} y_{t-1}+a_{12} z_{t-1}+e_{y t} \\
& z_{t}=a_{20}+a_{21} y_{t-1}+a_{22} z_{t-1}+e_{z t}
\end{aligned}
$$

$e_{y t}$ dan $e_{z t}$ adalah gabungan dari $\varepsilon_{y t}$ dan $\varepsilon_{z t}$. Bentuk yang primitive disebut VAR struktural, dan bentuk yang standar disebut VAR. Perubahan rinci dari bentuk primitive ke bentuk standard dapat dilihat di Enders (2004). Singkat kata, menurut Achsani et al., 2005, model VAR yang umum, secara matematis dapat digambarkan sebagai berikut.

$$
x_{t}=\mu_{t}+\sum_{i=1}^{k} A_{i}+X_{t-1}+\varepsilon_{t}
$$

$x_{t}$ adalah vektor variabel endogen dengan dimensi $(n \times 1), \mu_{t}$ adalah vektor variabel eksogen, termasuk konstanta (intercept) dan tren, $A_{i}$ adalah matriks koefisien dengan dimensi $(n \times n)$, dan $\varepsilon_{t}$ adalah vektor residu. Dalam sistem bivariate sederhana $y_{t}$ dan $z_{t}, y_{t}$ dipengaruhi oleh nilai $z_{t}$ sekarang dan masa lalu, sementara $z_{t}$ dipengaruhi oleh nilai $y_{t}$ sekarang dan masa lalu.

Untuk mengatasi kekurangan first-difference VAR dan untuk memperoleh kembali hubungan jangka panjang antar variabel, Vector Error Correction Model (VECM) dapat digunakan, selama ada kointegrasi antar variabel. Caranya adalah dengan memasukkan persamaan original dalam level ke dalam persamaan baru sebagai berikut.

$$
\begin{aligned}
& \Delta y_{t}=b_{10}+b_{11} \Delta y_{t-1}+b_{12} \Delta z_{t-1}-\lambda\left(y_{t-1}-a_{10}-a_{11} y_{t-2}-a_{12} z_{t-1}\right)+\varepsilon_{y t} \\
& \Delta z_{t}=b_{20}+b_{21} \Delta y_{t-1}+b_{22} \Delta z_{t-1}-\lambda\left(z_{t-1}-a_{20}-a_{21} y_{t-1}-a_{22} z_{t-2}\right)+\varepsilon_{z t}
\end{aligned}
$$

$a$ adalah koefisien regresi jangka panjang, $b$ adalah koefisien regresi jangka pendek, $\lambda$ adalah parameter koreksi error, dan frase di dalam kurung menunjukan kointegrasi antara variabel $y$ dan z. Model VECM yang umum, secara matematika dapat digambarkan sebagai berikut (Achsani et al, 2005).

$$
\Delta x_{t-1}=\mu_{t}+\prod x_{t-1}+\sum_{i=1}^{k-1} \Gamma_{i} \Delta x_{t-i}+\varepsilon_{t}
$$


$\Pi$ dan $\Gamma$ adalah fungsi dari $A_{i}$. Matrik $\Pi$ dapat diuraikan menjadi 2 matriks $\lambda$ dan $\beta$ dengan dimensi $(n \times r)$. $\Pi=\lambda \beta^{T}$, dimana $\lambda$ adalah adjustment matrix dan $\beta$ adalah vektor kointegrasi. Sedangkan $r$ adalah cointegration rank.

Proses analisis VAR dapat dibaca pada Diagram 3. Setelah data dasar siap, data ditransformasi ke bentuk logaritma natural (In), kecuali untuk tingkat suku bunga dan return bagi hasil, untuk mendapatkan hasil yang konsisten dan valid. Uji pertama yang dilakukan adalah uji unit root, untuk mengetahui apakah data stasioner atau masih mengandung tren. Jika data stasioner pada levelnya, maka VAR dapat dilakukan pada level. VAR level dapat mengestimasi hubungan jangka panjang antar variabel. Jika data tidak stasioner pada levelnya, maka data harus diturunkan pada tingkat pertama (first difference) yang mencerminkan data selisih atau perubahan. Jika data stasioner pada turunan pertama, maka data akan diuji untuk keberadaan kointegrasi antar variabel. Jika tidak ada kointegrasi antar variabel, maka VAR hanya dapat dilakukan pada turunan pertamanya, dan ia hanya dapat mengestimasi hubungan jangka pendek antar variabel. Innovation accounting tidak akan bermakna untuk hubungan jangka panjang antar variabel. Jika ada kointegrasi antar variabel, maka VECM dapat dilakukan menggunakan data level untuk mendapatkan hubungan jangka panjang antar variabel. VECM dapat mengestimasi hubungan jangka pendek maupun jangka panjang antar variabel.

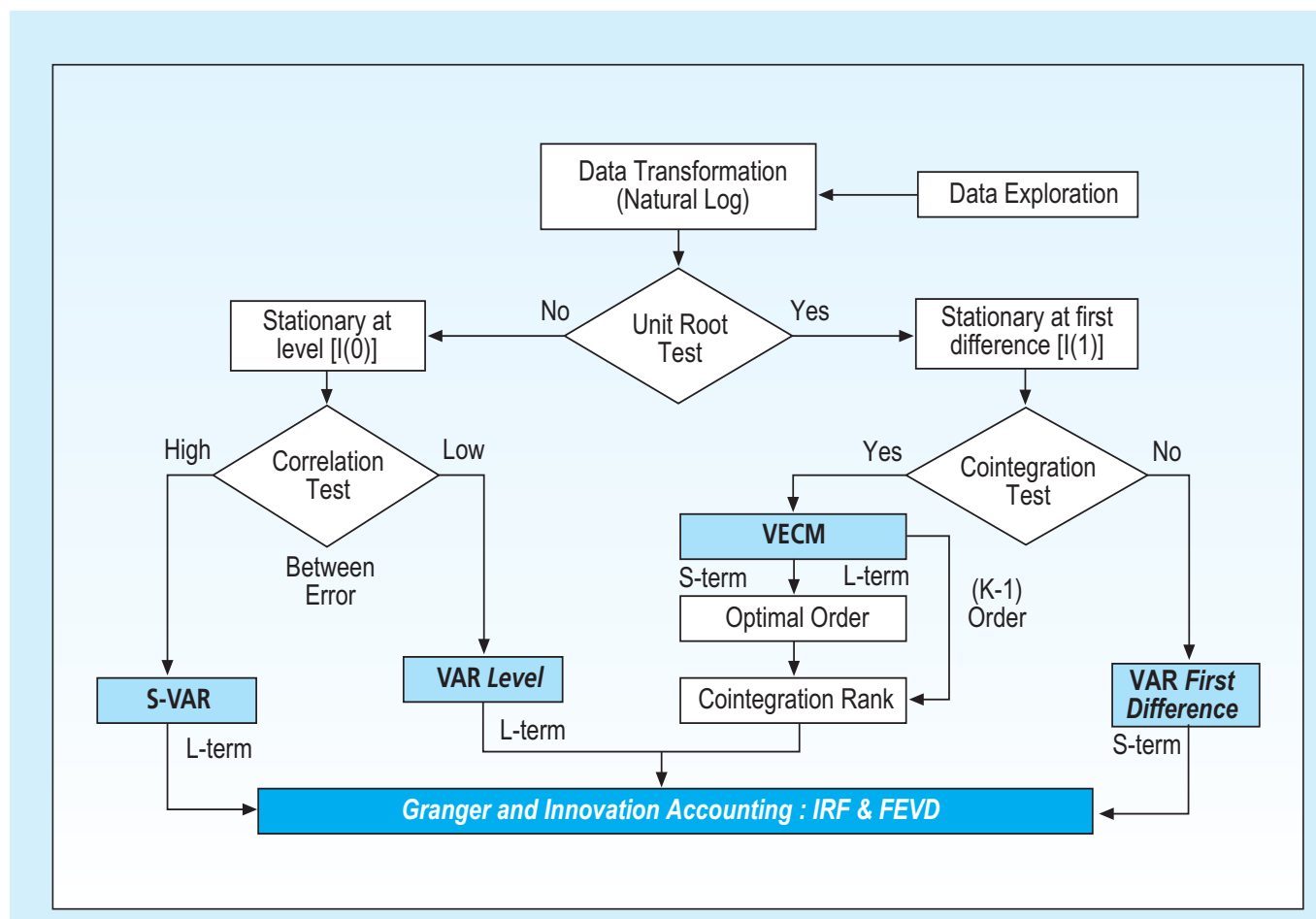

Diagram 3. 
Innovation accounting untuk VAR level dan VECM akan bermakna untuk hubungan jangka panjang.

Berdasarkan kerangka konseptual, permasalahan kedua pada penelitian ini akan dianalisis dengan menggunakan Vector Autoregression (VAR) dari model umum VAR, seperti pada Persamaan 16, dengan variabel-variabel endogen seperti dijelaskan sebelumnya.Dua model transmisi kebijakan moneter ganda yang akan digunakan adalah model output dan model inflasi, sebagai dua model pencapaian tujuan akhir kebijakan makro ekonomi.

Analisis impulse response function dilakukan untuk melihat respon suatu variabel endogen terhadap guncangan variabel lain dalam model. Analisis variance decomposititon juga dilakukan untuk melihat kontribusi relatif suatu variabel dalam menjelaskan variabilitas variabel endogenusnya. Data IHK, FINC, dan LOAN dalampenelitian ini ditransformasikan ke dalam bentuk logaritma natural (In) untuk mendapatkan hasil analisis yang lebih valid dan konsisten. Perangkat lunak yang digunakan dalam penelitian ini adalah Microsoft Excel 2007dan program Eviews 6.0.

\section{HASIL DAN ANALISIS}

Hasil pengujian stasioneritas datamenunjukkan hanya variabelIPI, FINC, dan PUAB yang stasioner pada level, sementara sisanya stasioner pada firstdifference.Uji kedua adalah menentukan lag optimal. Pengujian panjang lag optimal ini sangat berguna untuk menghilangkan masalah autokorelasi dalam sistem VAR, sehingga dengan digunakannya lag optimal diharapkan tidak muncul lagi masalah autokorelasi. Langkah pertama adalah menentukan panjang lag maksimum sistem VAR yang stabil, dimana kriteria stabil jika seluruh roots-nya memiliki modulus lebih kecil dari satu dan semuanya terletak di dalam unitcircle (Lutkepohl, 1991). Hasil perhitungan menunjukkan kisaran modulus 5 untuk model Output (IPI) dan 6 untuk model Inflasi (IHK) yang semuanya berada pada unit circle.

Langkah kedua adalah penentuan lag optimal berdasarkan lag terpendek dengan menggunakanHannan-Quinnon Criterion (HQ) atau Schwarz Information Criterion (SC). Hasil menunjukkan kedua model output dan inflasi memiliki lag optimal satu.

Uji ketiga adalah menentukan keberadaan kointegrasi antar variabel. Jika tidak ada kointegrasi antar variabel, maka VAR hanya dapat dilakukan pada turunan pertamanya, dan ia hanya dapat mengestimasi hubungan jangka pendek antar variabel. Innovation accounting tidak akan bermakna untuk hubungan jangka panjang antar variabel. Jika ada kointegrasi antar variabel, maka VECM dapat dilakukan menggunakan data level untuk mendapatkan hubungan jangka panjang antar variabel. VECM dapat mengestimasi hubungan jangka pendek maupun jangka panjang antar variabel. Innovationaccounting untuk VAR level dan VECM akan bermakna untuk hubungan jangka panjang. Uji kointegrasi berdasar tracestatistics digunakan untuk menentukan banyaknya sistem persamaan yang dapat menjelaskan hubungan jangka 
panjang. Hasilnya menunjukkan bahwa model output memiliki 6 (enam) persamaan terkointegrasi, sedangkan model inflasi memiliki 4 (empat) persamaan terkointegrasi pada nilai kritis 5\%.

\subsection{Granger Causality}

Model yang diuji terbagi menjadi dua, (i) output dan (ii) inflasi. Hasil Granger Causality untuk alur transmisi kebijakan moneter ganda dengan tujuan akhir output (IPI) di sisi konvensional menunjukkan adanya kesinambungan jalur suku bunga sesuai teori dari suku bunga acuan SBI ke PUAB dan ke INT, dari PUAB ke INT dan OUTPUT, dari INT ke LOAN dan kembali ke SBI danPUAB, serta dari LOAN ke OUTPUT. Setelah itu, OUTPUT memberikan pengaruh balik ke LOAN. Secara umum kenaikan SBI meningkatkan suku bunga dan menurunkan LOAN dan OUTPUT.

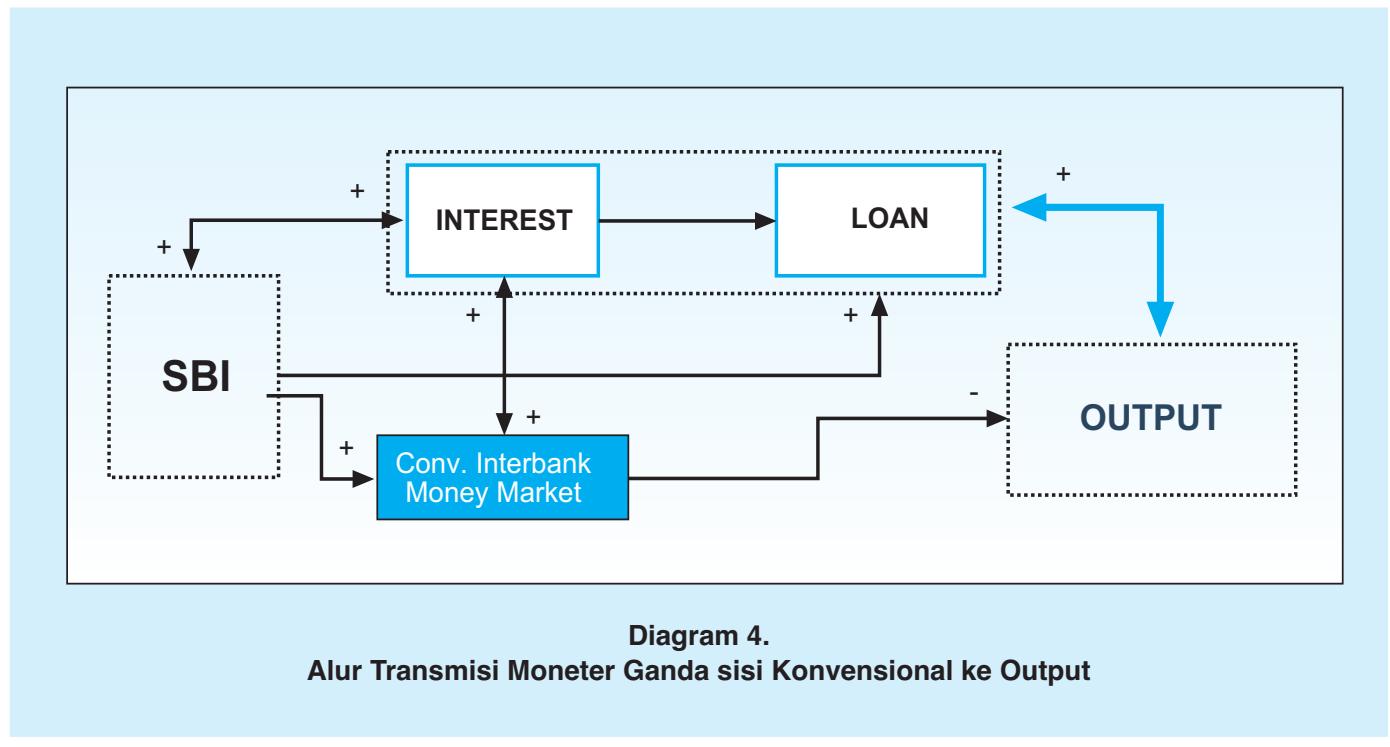

Sedangkan dari sisi system Syariah, hasil Granger Causality untuk alur transmisi kebijakan moneter ganda dengan tujuan akhir output (IPI) menunjukkan tidak adanya kesinambungan jalur imbal hasil dari margin acuan SBIS sampai ke OUTPUT. SBIS hanya mempengaruhi pasar keuangan ke PUAS. Sementara itu, PLS mempengaruhi FINANCING dan OUTPUT, sedangkan FINANCING mempengaruhi OUTPUT dan PUAS. Secara umum kenaikan imbal hasil SBIS hanya meningkatkan imbal hasil PUAS. Sedangkan peningkatan imbal hasil PLS meningkatkan FINANCING dan OUTPUT. 


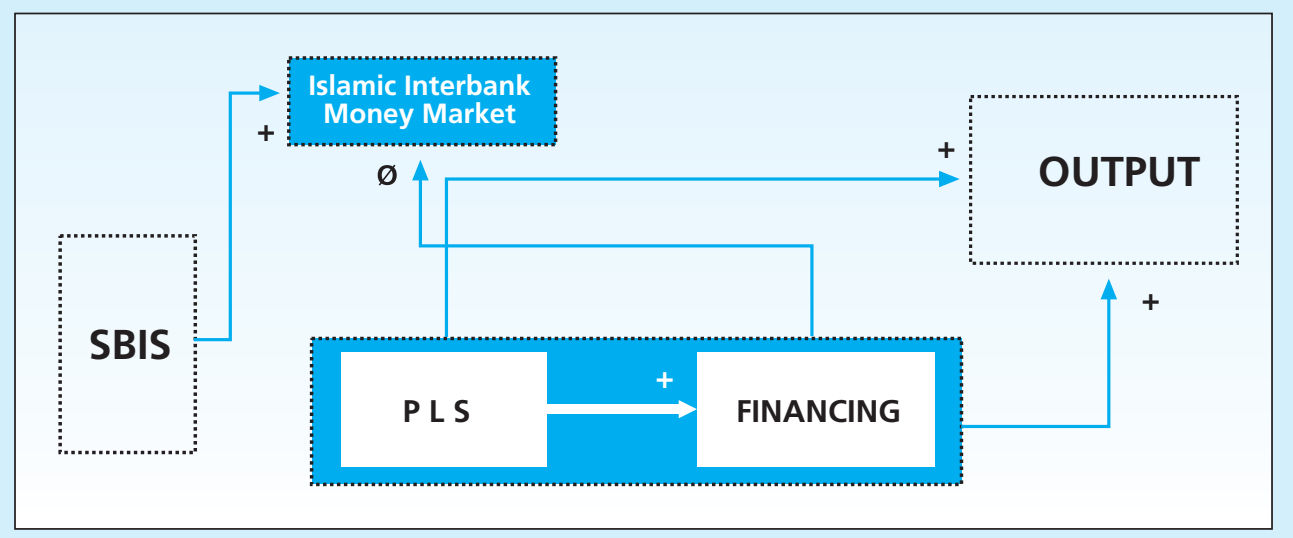

Diagram 5.

Alur Transmisi Moneter Ganda sisi Syariah ke Output

Untuk model inflasi, yakni alur transmisi kebijakan moneter ganda dengan tujuan akhir inflasi (IHK), hasil Granger Causalityuntuk system konvensional menunjukkan adanya kesinambungan jalur suku bunga sesuai teori dari suku bunga acuan SBI ke PUAB dan ke INT, dari PUAB ke INT, dari INT ke LOAN dan INFLATION dan kembali ke SBI danPUAB, serta dari LOAN ke INFLATION. Setelah itu, INFLATION memberikan pengaruh balik ke SBI. Secara umum kenaikan SBI meningkatkan suku bunga, menurunkan LOAN dan meningkatkan INFLATION.

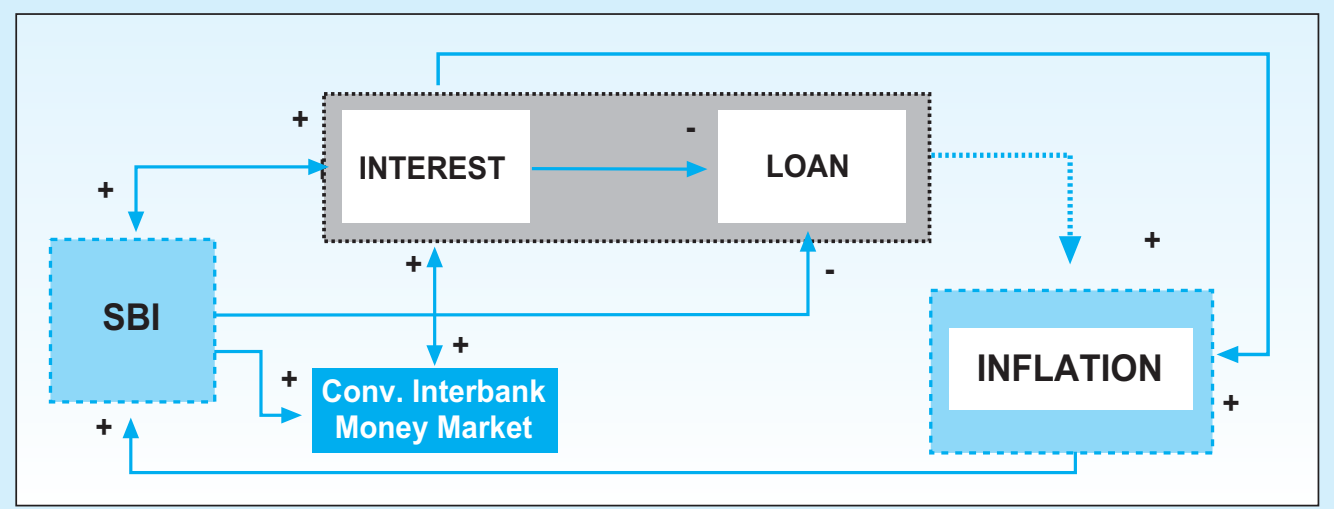

Diagram 6.

Alur Transmisi Moneter Ganda sisi Konvensional ke Inflasi 
Sedangkan, hasil Granger Causality untuk alur transmisi kebijakan moneter ganda model Inflasi (dengan tujuan akhir inflasi atau IHK) di sisi Syariah menunjukkan tidak adanya kesinambungan jalur imbal hasil dari margin acuan SBIS sampai ke INFLATION. SBIS hanya mempengaruhi imbal hasil pasar keuangan Syariah PUAS. Sementara itu, PLS mempengaruhi FINANCING, sedangkan FINANCING mempengaruhi PUAS. Sebaliknya, INFLATION banyak berpengaruh ke PUAS, PLS dan FINANCING. Secara umum kenaikan imbal hasil SBIS hanya meningkatkan imbal hasil PUAS. Sedangkan INFLATION menurunkan PLS dan meningkatkan FINANCING.

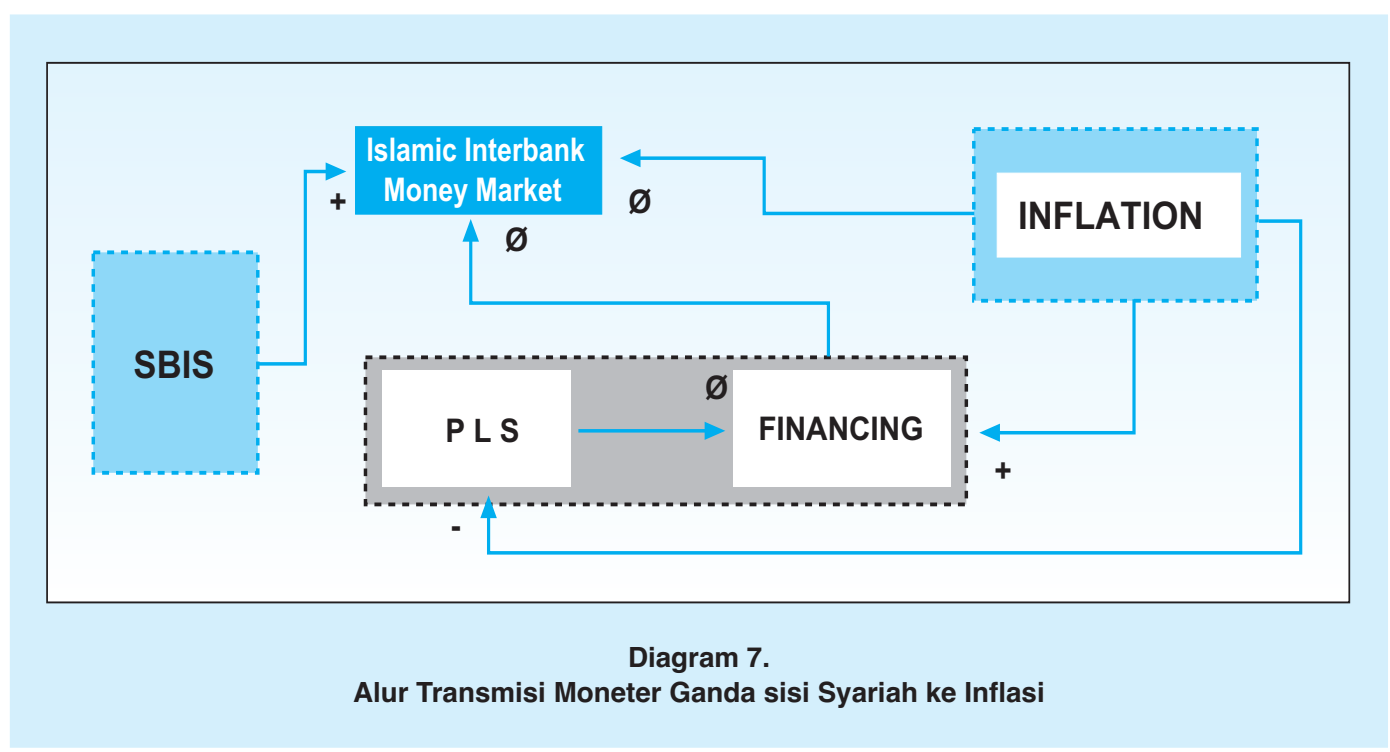

Dari hasil pengujian Granger di atas, dalam model Output, alur transmisi kebijakan moneter ganda dari sisi konvensional berkesinambungan sampai ke OUTPUT, terutama dari kredit, karena kredit konvensional adalah bagian kegiatan yang ada di sektor riil. Sedangkan, transmisi kebijakan moneter ganda dari sisi Syariah terpisah antara sektor finansial (SBIS dan PUAS) dan sektor riil (PLS dan FINANCING), dan hanya sisi sektor riil yang berkesinambungan sampai OUTPUT yang berada di sektor riil. Perlu dicatat bahwa dari sisi konvensional, kenaikan SBI secara keseluruhan berpengaruh negatif (menurunkan) output sektor riil karena dana semakin tertarik mengalir ke sektor finansial, bukan ke sektor riil.

Dalam model Inflasi, alur transmisi kebijakan moneter ganda dari sisi konvensional berkesinambungan sampai ke Inflasi, sedangkan alur transmisi kebijakan moneter ganda dari sisi Syariah tidak berkesinambungan sampai ke Inflasi. Hal ini dapat dijelaskan, antara lain, karena ekonomi konvensional berbasis bunga memiliki dua pasar yang dikotomis (pasar sektor finansial dan pasar sektor riil) dan pasar di sektor finansial bersifat inflatoir, sedangkan ekonomi Syariah berbasis non bunga dan berpusat di sektor riil yang tidak bersifat inflatoir. Oleh karena 
itu, bunga (yang merupakan harga di sektor finansial konvensional) mempengaruhi inflasi, sedang SBIS (yang bukan mencerminkan harga di sektor riil maupun sektor finansial) tidak mempengaruhi inflasi. Ketika masih berupa SWBI dan menggunakan akad wadiah, SBIS lebih dekat sebagai harga di sektor riil Syariah, sedang ketika berupa SBIS dan menggunakan akad ju'alah (namun imbal hasilnya disetarakan dengan SBI satu bulan), SBIS lebih dekat sebagai harga di sektor finansial konvensional.

Sisi konvensional lebih banyak mempengaruhi sisi Syariah dari kredit (LOAN) karena sistem moneter dan keuangan Indonesia masih didominasi $(97,4 \%)$ oleh sistem konvensional, dan bagian yang berhubungan dengan sektor riil adalah kredit, bukan suku bunga. Namun demikian, sisi Syariah lebih banyak mempengaruhi sisi konvensional dari imbal hasil pembiayaan (PLS) karena PLS berbasis sektor riil. Sedangkan, suku bunga kredit Konvensional (INT) tidak mempengaruhi sisi Syariah karena INT adalah harga uang di sektor finansial yang dipengaruhi oleh banyak hal.

Dari hasil secara keseluruhan, alur transmisi kebijakan moneter konvensional sesuai dengan teori, sedangkan alur transmisi kebijakan moneter Syariah belum dapat diidentifikasi secara jelas. Namun, instrumen Syariah yang menggunakan akad profit-and-loss sharing, seperti mudharabah dan musyarakah di PLS pembiayaan, berpengaruh positif ke OUTPUT di sektor riil, tetapi tidak berpengaruh negatif ke INFLASI di sektor finansial.

\subsection{Impulse Response Function}

Hasil Impulse Response Function (IRF) untuk alur transmisi kebijakan moneter ganda model Output menunjukkan bahwa semua varibel konvensional, yaitu kredit (LOAN), suku bunga (INT), pasar uang antarbank konvensional (PUAB) dan suku bunga acuan kebijakan moneter konvensional (SBI), menurunkan output dan bersifat permanen. Pada sisi lain semua varibel
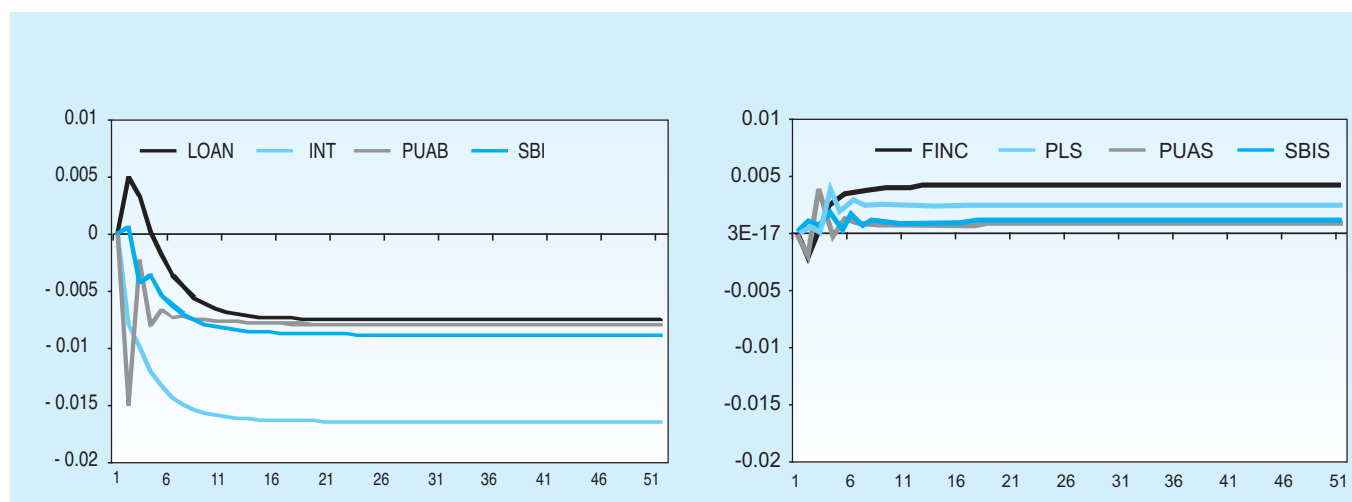

Grafik 4.

Impulse Response Function (IRF) untuk Model Output 
Syariah, yaitu pembiayaan (FINC), bagi hasil (PLS), pasar uang antarbank Syariah (PUAS) dan imbal hasil acuan kebijakan moneter Syariah (SBIS), memberikan dampak positif dalam pengertian meningkatkan output dan juga bersifat permanen.

Pengaruh gejolak atau shock variabel-variabel konvensional terhadap output mereda dan stabil pada periode 16-21, sedangkan pengaruh gejolak atau shock variabel-variabel Syariah terhadap output mereda dan stabil lebih cepat pada periode 11-16. Suku bunga pada sistem konvensional (di sektor finansial) memberikan dampak negatif (menghambat) terbesar terhadap output, sedangkan pembiayaan (FINC) Syariah (di sektor riil) memberikan dampak positif (mendorong) terbesar terhadap output.

Untuk model inflasi (IHK), hasil Impulse Response Function menunjukkan bahwa semua varibel konvensional(kecuali suku bunga acuan kebijakan moneter konvensional SBI), yaitu volume kredit (LOAN), suku bunga (INT), dan pasar uang antarbank konvensional (PUAB), memberikan dampak inflationer terhadap inflasi dan bersifat permanen. Pada sis lain, semua varibel Syariah, yaitu pembiayaan (FINC), bagi hasil (PLS), pasar uang antarbank Syariah (PUAS) dan imbal hasil acuan kebijakan moneter Syariah (SBIS), memberikan dampak positif dalam pengertian berdampak menurunkan inflasi dan juga bersifat permanen.
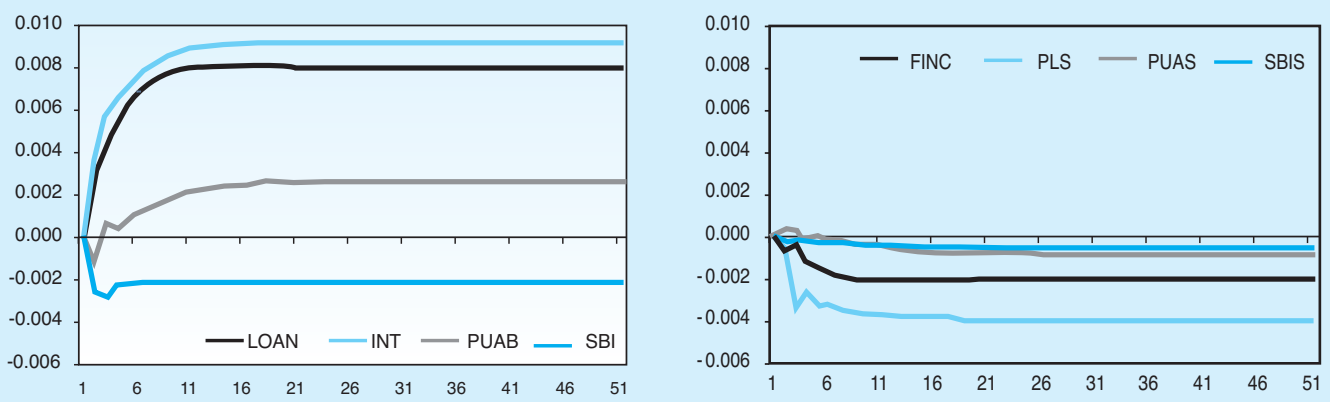

Grafik 5.

Impulse Response Function (IRF) untuk Model Inflasi

Pengaruh gejolak atau shock variabel-variabel konvensional terhadap inflasi mereda dan stabil pada periode 8-21, sedangkan pengaruh gejolak atau shock variabel-variabel Syariah terhadap inflasi mereda dan stabil sedikit lebih cepat pada periode 9-19. Diantara semua variabel pada system konvensional, suku bunga kredit (INT) memberikan dampak negatif (memicu dan meningkatkan) terbesar terhadap inflasi, sedangkan bagi hasil pembiayaan (PLS) Syariah (di sektor riil) memberikan dampak positif (menahan dan menurunkan) terbesar terhadap inflasi. 
Perilaku suku bunga (konvensional) dan bagi hasil (Syariah) ditunjukkan senada oleh perilaku kredit (LOAN) konvensional dan pembiayaan (FINC) Syariah, karena kredit dipengaruhi oleh suku bunganya, sedangkan pembiayaan dipengaruhi oleh bagi hasilnya, sehingga kredit berdampak negatif terhadap inflasi maupun output, sedangkan pembiayaanberdampak positif terhadap inflasi dan output.

Sementara itu, perilaku suku bunga konvensional dan bagi hasil Syariah juga ditunjukkan oleh suku bunga pasar uang antarbank konvensional (PUAB) dan imbal hasil pasar uang antarbank Syariah (PUAS), karena suku bunga PUAB merupakan acuan suku bunga perbankan konvensional, sedangkan imbal hasil PUAS dengan akad mudharabah berbasis imbal hasil di sektor riil, seperti bagi hasil pembiayaan (PLS), sehingga PUAB berdampak negatif terhadap inflasi maupun output, sedangkan PUAS berdampak positif terhadap inflasi dan output.

Lebih jauh lagi, perilaku imbal hasil acuan kebijakan moneter Syariah (SBIS) juga menunjukkan perilaku yang sama dengan variabel-variabel Syariah lainnya yang memiliki karakter positif dalam menghambat dan menurunkan inflasi serta dalam mendorong dan meningkatkan output atau pertumbuhan ekonomi.

Sementara itu, dampak gejolak (kenaikan) SBI dapat mempengaruhi (menahan) inflasi, namun pada saat yang bersamaan juga berdampak negatif terhadap output. Pengaruh SBI terhadap inflasi merupakan premis ekonomi konvensional untuk menggunakan SBI sebagai instrumen moneter utama dalam mengendalikan inflasi. Namun, perlu dicatat bahwa pengaruh negatif tiga variabel konvensional lainnya (PUAB, INTEREST dan LOAN) jauh lebih besar dari pada pengaruh positif SBI terhadap inflasi.

Dampak suku bunga dan bagi hasil terhadap inflasi sesuai dengan kajian empiris Ascarya (2009a dan 2009b), dimana suku bunga merupakan salah satu penyebab inflasi, sedangkan bagi hasil tidak menyebabkan inflasi. Dampak suku bunga dan bagi hasil terhadap output sesuai dengan kajian teori dan kajian empiris Ryandono (2006) dan Ascarya et al. (2007), dimana suku bunga berpengaruh negatifterhadap output atau pertumbuhan ekonomi, sedangkan bagi hasil berpengaruh positif terhadap output atau pertumbuhan ekonomi. Ketika suku bunga naik, investasi akan turun, sehingga akan menurunkan output. Sementara itu, ketika bagi hasil naik, investasi naik, sehingga meningkatkan output.

\subsection{Forecast Error Variance Decomposition}

Untuk model alur transmisi kebijakan moneter ganda dengan tujuan akhir output (model IPI), hasil Forecast Error Variances Decomposition (FEVD) menunjukkan bahwa variabel-varibel konvensional yang memberik sumbangan negatif (penghambat) output terbesar meliputisuku bunga (18,13\%), SBI (5,02\%), PUAB (4,57\%) dan LOAN (3,57\%). Pada sisi lain, variabel- 
varibel Syariah ternyata merupakan penyumbang positif dalam pengertian merupakan pendorong output, meskipun masih kecil, seperti FINC (1.12\%) dan PLS (0.36\%).

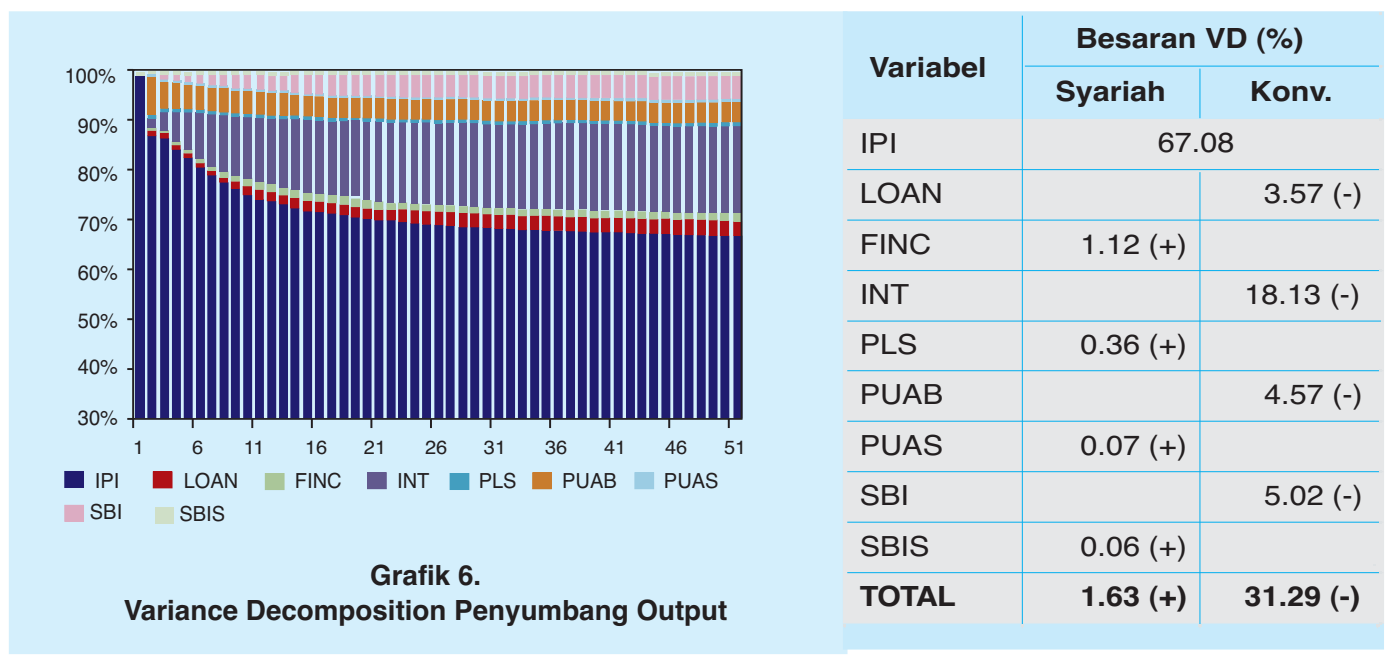

Untuk model alur transmisi kebijakan moneter ganda dengan tujuan akhir inflasi (model IHK), hasil Forecast Error Variances Decomposition (FEVD) menunjukkan bahwa variabel-varibel konvensional yang merupakan penyumbang negatif atau pemicu inflasi terbesar meliputisuku bunga (25,23\%), volume kredit atau LOAN (19,43\%) dan PUAB (1,87\%), kecuali SBI yang merupakan penyumbang positif (penghambat) INFLASI sebesar 1,52\%. Sedangkan, variabelvaribel Syariah merupakan penyumbang positif dalam pengertian merupakan penghambat INFLASI meskipun masih kecil, seperti PLS (4,63\%) dan FINC (1,31\%).

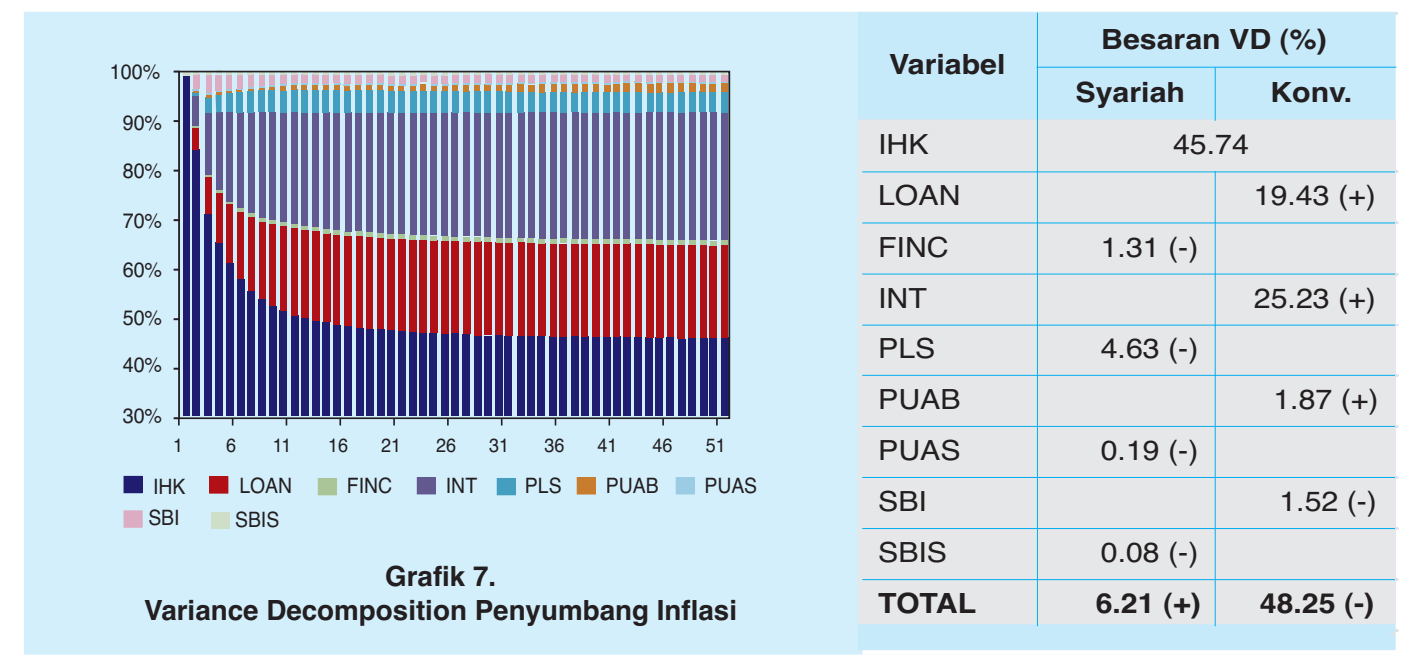


Hasil di atas menunjukkan bahwa secara keseluruhan, variabel-variabel konvensional merupakan penghambat, sementara variabel-variabel Syariah merupakan pendorong pertumbuhan ekonomi. Secara agregat, variabel-variabel konvensional ini memberikan kontribusi negatif terhadap pertumbuhan ekonomi sebesar 31,29\%, sedangkan variabel-variabel Syariah berkontribusi positif terhadap pertumbuhan ekonomi sebesar 1,62\%.

Sementara itu, dalam rangka mencapai kestabilan harga atau inflasi, secara keseluruhan, variabel-variabel konvensional memicu inflasi, sedangkan variabel-variabel Syariah menahan inflasi, kecuali SBI (konvensional) yang terlihat mempunyai andil menahan inflasi sebesar 1,52 persen. Untuk tujuan INFLASI, secara keseluruhan, variabel-variabel konvensional memicu inflasi $(46,53 \%)$, sedangkan variabel-variabel Syariah menahan inflasi $(6,21 \%)$.

Hasil-hasil di atas secara umum menunjukkan bahwa variabel-variabel konvensional, yang utamanya adalah variabel sektor finansial, secara alamiah memicu inflasi dan menghambat pertumbuhan ekonomi, sedangkan variabel-variabel Syariah, yang utamanya adalah variabel sektor riil, secara alamiah tidak memicu inflasi dan mendorong pertumbuhan ekonomi.

Perilaku SBI dalam menahan inflasi ketika kontraksi moneter sesuai dengan praktek kebijakan moneter konvensional selama ini, namun memicu inflasi melalui peningkatan suku bunga kredit dan menghambat pertumbuhan ekonomi.

\section{KESIMPULAN}

Paper empiris ini memberikan beberapa temuan penting, pertama, berdasarkan uji kasalitas Granger, secara keseluruhan, alur transmisi kebijakan moneter konvensional sesuai dengan teori, sedangkan alur transmisi kebijakan moneter Syariah belum dapat diidentifikasi secara jelas dan terputus di PUAS. Namun, instrument Syariah yang menggunakan akad profit-andloss sharing, seperti mudharabah dan musyarakah di PLS pembiayaan, berpengaruh positfi terhadap output sektor riil dan tidak berpengaruh ke inflasi.

Kedua, dari hasil IRF secara keseluruhan, gejolak SBI, PUAB, suku bunga dan kredit (konvensional) berdampak negatif dan permanen terhadap inflasi dan pertumbuhan ekonomi (kecuali SBI ke inflasi), serta menunjukkan indikasi adanya perilaku spekulatif. Pada sisi lain, gejolak pada SBIS, PUAS, bagi hasil dan pembiayaan Syariah berdampak positif dan permanen terhadap inflasi dan pertumbuhan ekonomi, serta tidak menunjukkan indikasi adanya perilaku spekulatif.

Ketiga, mengacu pada variance docomposition, secara keseluruhan, variabel-variabel konvensional yang utamanya adalah variabel sektor finansial, secara alamiah memiliki andil dalam memicu inflasi dan menghambat pertumbuhan ekonomi. Terdapat pengecualian untuk SBI (konvensional) yang terlihat mempunyai andil menahan inflasi sebesar 1,52 persen. Andil SBI dalam menahan inflasi ketika kontraksi moneter sesuai dengan praktek kebijakan moneter 
konvensional selama ini, namun memicu inflasi melalui peningkatan suku bunga kredit dan menghambat pertumbuhan ekonomi. Pada sisi lain, variabel-variabel Syariah yang utamanya adalah variabel sektor riil, secara alamiah memiliki andil dalam menahan inflasi dan mendorong pertumbuhan ekonomi.

Tiga temuan tersebut mengarahkan pada kesimpulan empiris bahwa kebijakan moneter untuk 'pengurangan inflasi' dengan pola Syariah lebih efektif dari pada dengan pola Konvensional. Kesimpulan ini memberikan beberapa implikasi logis, (i) bahwa dalam sistem moneter ganda, alternatif pendekatan kebijakan moneter dapat dilakukan dengan menggunakan pendekatan kuantitatif yang tidak bertentangan untuk konvensional maupun Syariah. Hal ini sejalan dengan usulan strategi dari Choudhury (1997), Ascarya, et al. (2007) dan Ascarya dan Sakti (2008); (ii) pendekatan harga masih dapat digunakan, namun dengan menggunakan Real Rateof Return sebagai Policy Rate, sehingga dapat applicable untuk Konvensional maupun Syariah. Hal ini juga sejalan dengan Ryandono (2006), Ascarya, et al. (2007), Ascarya, et al. (2008), Ascarya (2009), dan Ascarya dan Yumanita (2009), sehingga kebijakan moneter tidak hanya 'to control inflation', tetapi juga 'to eradicate infation'; (iii) sejalan dengan poin (i) dan (ii) ini, maka SBIS sebaiknya menggunakan akad bagi hasil (mudharabah atau musharakah), bukan fee based (ju'alah), untuk lebih memberikan efek stabilitas makro ekonomi dan mengurangi tingkat inflasi. 


\section{DAFTAR PUSTAKA}

Achsani, N.A., O. Holtemöller and H. Sofyan, 2005. "Econometric and Fuzzy Modelling of Indonesian Money Demand." in: Pavel Cizek, Wolfgang H., and Rafal W. Statistical Tools For Finance and Insurance. Berlin Heidelberg, Germany: Springer-Verlag.

Alamsyah, Halim dan Abdul Kadir Masyhuri. 2000. "Inflation Targeting Sebagai Kerangka Kerja Alternatif Bagi Kebijakan Moneter." "Paper. Mimeo.

Ascarya. 2007. Akad dan Produk Bank Syariah. Jakarta, Indonesia: Rajawali Pers.

Ascarya. 2008. "Menuju Sinergi Optimal Kebijakan Moneter dalam Sistem Keuangan/Perbankan Ganda." "Jurnal Ekonomi dan Bisnis Indonesia Vol.23, No.1.

Ascarya. 2009a. "Lessons Learned from Repeated Financial Crises: An Islamic Economic

Perspective." "Buletin Ekonomi Moneter dan Perbankan, Bank Indonesia, Vol.12, No.1.

Ascarya. 2009b. "The Determinants of Inflation under Dual Monetary System in Indonesia." "Working Paper, Bank Indonesia.

Ascarya. 2009c. "Toward Optimum Synergy of Monetary Policy in Dual Financial/Banking System." "Journal of Indonesian Economy and Business, Vol.24, No.1.

Ascarya. 2010. "Peran Perbankan Syariah dalam Transmisi Kebijakan Moneter Ganda di Indonesia." "Iqtisodia, Republika, August 26.

Ascarya and Ali Sakti. 2008. "Comparing Monetary Policy Instruments under Dual Financial

System: Interest System vs. Profit-and-Loss Sharing System." "Journal of Islamic Business and Economics, Vol. 2, No. 1, Yogyakarta: Laboratorium Ekonomi dan Bisnis Islam.

Ascarya, Ali Sakti, Noer A. Achsani, and Diana Yumanita. 2007.

"Towards Integrated Monetary Policy under Dual Financial System: Interest System vs. Profitand-Loss Sharing System." "Working Paper, Bank Indonesia.

Ascarya and Diana Yumanita. 2009. "Formulasi Stabilitas Sistem Keuangan Ganda di Indonesia." "Working Paper, Bank Indonesia.

Ascarya, Heni Hasanah, and Noer A. Achsani. 2008. "Perilaku Permintaan Uang dalam Sistem

Moneter Ganda di Indonesia." "Buletin Ekonomi, Moneter dan Perbankan Bank Indonesia Vol. 11, No. 1. Jakarta: Bank Indonesia.

Aydin, Halil Ibrahim. 2007. "Interest Rate Pass-Through in Turkey." Central Bank of Turkey Working Paper.

'Ayuniyyah, Qurroh, Noer A. Achsani, and Ascarya. 2010. "Analisis Pengaruh Instrumen Moneter Syariah dan Konvensional terhadap Pertumbuhan Sektor Riil di Indonesia." "Iqtisodia, Republika, August 26.

Banerjee, Anindyaet al.1998. "Error-Correction Mechanism Tests for Cointegration in a SingleEquation Framework." Journal of Time Series Analysis Vol. 19 No. 3. Blackwell Publishers Ltd. 
Best, Robin.2008. "An Introduction to Error Correction Models. "LectureNotes. Oxford Spring School for Quantitative Methods in Social Research.

Betancourt, Rocio, Hernando Vargas, dan Norberto Rodriguez. 2008. "Interest Rate Pass-Through in Columbia." "Cuadernos de Economia Vol.45 (Mayo) pp.29-58.

Bredin, Don, Trevor Fitzpatrick, dan Gerard O Reilly.2001."Retail Interest Rate Pass-Through:

The Irish Experience." Technical PaperNo.06/RT/01. Central Bank of Ireland.

Burgstaller, Johann. 2005. "Interest Rate Pass-Through Estimates from Vector Autoregressive Model." "Mimeo.

Chapra, M. Umer. 1985. Towards a Just Monetary System. Leicester, UK: The Islamic Foundation. Chapra, M. Umer. 1996. "Monetary Management in an Islamic Economy." "Islamic Economic Studies Vol. 4, No. 1.

Chapra, M. Umer. 2000.

"Why has Islamic Prohibited Interest?" "Review of Islamic Economics, No. 9.

Choudhury, Masudul Alam. 1997. Money in Islam: A Study in Islamic Political Economy, London, UK: Routledge.

Chionis, Dionysios dan Costas A. Leon.2006. "Interest Rate Transmission in Greece: Did EMU Cause a Structural Break?" Journal of Policy Modeling No.28 pp.453-466.

Chmielewski, Tomasz. 2004. "Interest Rate Pass-Through in the Polish Banking Sector and Banking Specific Financial Disturbances." "Mimeo. National Bank of Poland.

Crespo-Cuaresma, Jesus, Balazs Egert, dan Thomas Reininger. 2004.

"Interest Rate Pass-Through in New EU Member States: The Case of the Czech Republic, Hungary, and Poland." "William Davidson Institute Working Paper No.671 May.

De Bondt, Gabe. 2002. "Retail Bank Interest Rate Pass-Through: New Evidence at the Euro Area Level." European Central Bank Working Paper Series No.136 April.

Direktorat Pengelolaan Moneter (DPM). 2006. Tinjauan Pelaksanaan OPT Era BI Rate dan Alternatif Penyempurnaannya." "Kajian IKU. Bank Indonesia.

Egert, Balazs, Jesus Crespo-Cuaresma dan Thomas Reininger. 2006. "Interest Rate Pass-Through in Central and Eastern Europe: Reborn from Ashes Merely to Pass Away?" "William Davidson Institute Working Paper No.851 November.

Enders, Walter. 2004. Applied Econometric Time Series. $2^{\text {nd }}$ Edition. John Wiley \& Sons. USA. Espinosa-Vega, Marco A. dan Alessandro Rebucci. 2003. "Retail Bank Interest Rate Pass-Through:

Is Chile Atypical?" "IMF Working Paper No.WP/03/112.

Gujarati, Damodar N. 2004. BasicEconometrics. $4^{\text {th }}$ Edition. Mc.Graw-Hill.

Horvath, Csilla, Judit Kreko, dan Anna Naszodi. 2005. "Interest Rate Pass-Through: The Case of Hungary." "Mimeo.

International Islamic University Malaysia. 2002.

International Conference on Stable and Just Global Monetary System: Viability of the Islamic

Gold Dinar, Proceedings, International Islamic University Malaysia, Kuala Lumpur, August 19-20.

Islahi, Abdul Azim. 1997. Konsepsi Ekonomi Ibnu Taimiyah. Bina ilmu. 
Karim, Adiwarman A. 2004. Sejarah Pemikiran Ekonomi Islam. Jakarta, Indonesia: Rajawali Pers.

Karim, Adiwarman A. 2007. Ekonomi Makro Islami. Jakarta, Indonesia: Rajawali Pers.

Khan, Muhammad Akram. 1999. An Introduction to Islamic Economics. Kitab Bhavan - New Delhi.

Keele, Luke dan Suzanna De Boef. 2004."Not Just for Cointegration: Error Correction Models with Stationary Data." http://www.nuffield.ox.ac.uk/Politics/papers.

Kwapil, Claudia dan Johann Scharler. 2006. "Interest Rate Pass-Through, Monetary Policy Rules and Macroeconomic Stability." Oesterreichische Nationalbank Working Paper No.18.

Kobayashi, Teruyoshi. 2008. "Incomplete Monetary Pass-Through and Optimal Monetary Policy." "International Journal of Central Banking Vol.4 No.3 September.

Marotta, Giuseppe. 2007. "Structural Breaks in the Lending Interest Rate Pass-Through and the Euro." "Mimeo. Dipartimento di Economia Politica, Università di Modena e Reggio Emilia, and CEFIN.

Meera, Ahamed Kameel M. 2004. The Theft of Nations: Returning to Gold. Subang Jaya, Malaysia: Pelanduk Publications.

Qayyum Abdul, Sajawal Khan, dan Idrees Khawaja. 2005. "Interest Rate Pass-Through in Pakistan: Evidence from Transfer Function Approach." The Pakistan Development Review Vol.44 No.4 pp.975-1001.

Sakti, Ali. 2007. Sistem Ekonomi Islam: Jawaban atas Kekacauan Ekonomi Modern. Jakarta, Indonesia: Paradigma \& Aqsa Publishing.

Siddiqui, Shamin Ahmad. 2008. "An Evaluation of Research on Monetary Policy and Stability of the Islamic Economic System." "Paper. $7^{\text {th }}$ International Conference on Islamic Economics: 30 Years of Research in Islamic Economics, Jeddah: KAAU-IRTI, April.

Sorensen, Christoffer Kok dan Thomas Werner. 2006. "Bank Interest Rate Pass-Through in the Euro Area: A Cross Country Comparison." "ECB Working Paper Series No. 580.

Sukmana, Raditya and Salina H. Kassim. 2010. "Roles of the Islamic Banks in the Monetary Transmission Process in Malaysia." "International Journal of Islamic and Middle Eastern Finance and Management, Vol. 3, No. 1.

Warjiyo, Perry dan Juda Agung [Eds]. 2002. Transmission Mechanisms of Monetary Policy in Indonesia. Jakarta: Bank Indonesia.

Tieman, Alexander. 2004. "Interest Rate Pass-Through in Romania and Other Central European Economies." IMF Working PaperNo.WP/04/211.

Van Leuvensteijn, Michiel, Christoffer Kok Sorensen, Jacob A. Bikker, dan Adrian ARJM van Rixtel. 2008. "Impact of Bank Competition on the Interest Rate Pass-Through in the Euro Area." "ECB Working Paper Series No.885. 